\title{
Industrial Electricity Usage and Stock Returns
}

\author{
Zhi Da, Dayong Huang, and Hayong Yun*
}

\begin{abstract}
The growth rate of industrial electricity usage predicts future stock returns up to 1 year with an $R^{2}$ of $9 \%$. High industrial electricity usage today predicts low stock returns in the future, consistent with a countercyclical risk premium. Industrial electricity usage tracks the output of the most cyclical sectors. Our findings bridge a gap between the asset pricing literature and the business cycle literature, which uses industrial electricity usage to gauge production and output in real time. Industrial electricity growth compares favorably with traditional financial variables, and it outperforms Cooper and Priestley's output gap measure in real time.
\end{abstract}

\section{Introduction}

Can stock market returns be predicted? This question is central to asset pricing, portfolio choice, and risk management. The general finding in the literature is that price-based financial variables tend to predict stock returns better than quantity-based macroeconomic indicators (Campbell (2003), Cochrane (2008), and Lettau and Ludvigson (2009), among others). This finding is discomfiting, as expected returns should ultimately be linked to the business cycle. In fact, a countercyclical risk premium is predicted by almost all leading asset pricing models, whether they are consumption-based (Campbell and Cochrane (1999), Bansal and Yaron (2004), among others) or production-based models (Cochrane (1991), Zhang (2005), Li, Livdan, and Zhang (2009), and Liu, Whited, and Zhang (2009), among others). However, many of the traditional business cycle variables, such as the growth rate of the gross domestic product (GDP), do not forecast stock returns (Pena, Restoy, and Rodriguez (2002)). One recent exception (Cooper and Priestley (2009)) finds that the deviation of log industrial production

*Da, zda@nd.edu, Mendoza College of Business, University of Notre Dame; Huang, d_huang $@$ uncg.edu, Bryan School of Business and Economics, University of North Carolina at Greensboro; and Yun (corresponding author), yunha@bus.msu.edu, Eli Broad College of Business, Michigan State University. We thank Hendrik Bessembinder (the editor), Tom Cosimano, Bjorn Eraker, Wayne Ferson, Ravi Jagannathan, Bill McDonald, Stavros Panageas, Jesper Rangvid, Marco Rossi, Raman Uppal, Annette Vissing-Jorgensen, Jason Wei, Xiaoyan Zhang, and an anonymous referee for helpful comments. We thank Manisha Goswami, Steve Hayes, Dongyoup Lee, and Liang Tan for data support. Any errors are our own. 
from its long-run trend, also known as the output gap, predicts stock market returns well. ("Log" refers to natural logarithm throughout.)

In this paper, we propose a novel yet simple business cycle variable that predicts stock market returns well and even outperforms the output gap when used in real time. This variable is the growth rate of the aggregate industrial usage of electricity.

Most modern industrial production activities involve the use of electricity. Crucially, because of technological limitations, electricity cannot easily be stored. As a result, industrial electricity usage can be used to track production and output in real time. ${ }^{1}$ Indeed, since 1971, the Federal Reserve ("the Fed") has been using survey data on electric power when estimating key components of its monthly industrial production index. The practice was discontinued in 2005 , due to poor survey coverage. ${ }^{2}$

Because electric utilities are highly regulated and are subject to extensive disclosure requirements, electricity usage data are accurately measured and reported. For these reasons, the business cycle literature has long used industrial electricity usage as a proxy for capital services (Jorgenson and Griliches (1967), Burnside, Eichenbaum, and Rebelo (1995), (1996), and Comin and Gertler (2006)). Capacity utilization, which is reflected in industrial electricity usage, appears to be the key missing ingredient that allows a relatively mild productivity shock to drive a much more volatile business cycle (King and Rebello (2000)). Despite the importance of industrial electricity usage as a business cycle variable, its predictive power for stock market returns has not been examined in the literature. Our paper fills this gap.

Because monthly industrial electricity usage data are available in the United States in our sample period, 1956-2010, we first conduct overlapping monthly predictive regressions to maximize the power of the test. To alleviate the impact of within-year seasonality in electricity usage, we compute year-over-year growth rates. For example, we use the industrial electricity growth rate from January in year $t-1$ to January in year $t$ to predict the excess stock return in February in year $t$. We then use the electricity growth rate from February in year $t-1$ to February in year $t$ to predict the excess stock return in March in year $t$, and so on. Stambaugh (1999) argues that predictive regressions potentially lead to overestimated $t$-values with a small sample in an overlapping regression because many predictive variables are persistent. To address this bias, we follow $\mathrm{Li}, \mathrm{Ng}$, and Swaminathan (2013) closely and report $p$-values from simulation exercises. For comparison purposes, we also report the more standard Hodrick (1992) $t$-value.

We find that this simple year-over-year industrial electricity usage growth rate has strong and significant predictive power for future stock market excess returns in horizons ranging from 1 month up to 1 year. At the annual horizon, a $1 \%$ increase in the year-over-year industrial electricity usage growth rate

\footnotetext{
${ }^{1}$ As anecdotal evidence, the Chinese premier relies on electricity consumption as a more accurate measure of economic growth in China. "All other figures, especially GDP statistics, are 'man-made' and therefore unreliable.” See Wall Street Journal, Dec. 6, 2010.

${ }^{2}$ The survey was conducted by the regional Federal Reserve Banks of the electric utilities in their district; it was not the Department of Energy/Energy Information Administration survey that we use in this paper.
} 
predicts an excess stock return that is $0.92 \%$ lower in the next year, with an $R^{2}$ of $8.64 \%$.

Compared with commercial and residential electricity usage, industrial electricity usage is less affected by weather conditions. Nevertheless, to make sure our results are not driven by weather changes, we orthogonalize industrial electricity growth on a weather-change variable and focus on the residual. The weatheradjusted electricity usage growth rate produces very similar results, suggesting that any potential weather-effect remnants in our year-over-year electricity growth rate are not driving the predictive results.

The in-sample predictive power of the industrial electricity usage growth rate compares favorably to 10 well-known return predictors that are based on financial information. These predictive variables include dividend-price ratio, earningsprice ratio, book-to-market ratio, Treasury bill rates, the default premium, the term premium, net equity issuance, inflation, returns on long-term government bonds, and stock variance. These predictors are associated with much lower $R^{2}$ values, and their regression coefficients are in general insignificant, with the inflation rate and the returns on long-term government bonds as the exceptions. When we include industrial electricity usage growth with the 10 predictors, one at a time, in the same predictive regression, electricity growth drives out all the financial variables except the inflation rate and the returns on long-term government bonds.

We also compare industrial electricity growth to several predictors that are based directly on industrial production. The first is the year-over-year growth rate in monthly industrial production. The second is the year-over-year change in monthly capital utilization. The next two are production growth from the fourth quarter of the previous year to the fourth quarter of this year and production growth from the third quarter of this year to the fourth quarter of this year. The last predictor is the in-sample output gap investigated by Cooper and Priestley (2009), who measure the gap as the deviation of log industrial production from its longrun trend using the full sample for regression. These five measures are all highly correlated with industrial electricity growth. At an annual frequency, the correlations of industrial electricity growth with industrial-output growth from December to December, or fourth quarter to fourth quarter, or third quarter to fourth quarter, and capacity utilization, are all above $60 \%$; the correlation with the in-sample output gap is lower but still at $36 \%$. The high correlations are not surprising because industrial-output-based measures, just like industrial electricity usage, are business cycle variables, as evidenced by their high correlations with the National Bureau of Economic Research (NBER) expansion indicator.

Which business cycle variable is the best predictor of future market returns? We find the in-sample output gap to be the strongest predictor. It has an $R^{2}$ of more than $16 \%$ for predicting next-year market excess returns, and the regression slope coefficients are highly significant. Nevertheless, we find that industrial electricity usage growth comes in second, and it outperforms the remaining industrial-output-based measures, including various versions of industrial-output growth, capacity utilization, and the out-of-sample output gap, which computes the gap using backward rolling windows. In addition, even though the in-sample output gap outperforms industrial electricity usage growth on a standalone basis, 
when they are included in the same regression, we find that industrial electricity usage growth remains significant. This finding suggests that industrial electricity usage has incremental return predictive power.

How can industrial electricity growth outperform the industrial-output growth rate in predicting future stock returns? We examine this question in detail by zooming in on industrial output from the 14 different industries that account for most of the total industrial output. We first regress the output growth in each industry on the electricity growth rate. The regression coefficient therefore measures the output's sensitivity to electricity usage for each industry. The industries with the highest sensitivity to electricity usage are steel, machinery, fabricated products, and construction. These industries are likely to be more capital-intensive, which is consistent with the high sensitivity of their output to electricity usage. ${ }^{3}$

The output growth rates of these four industries are highly cyclical. One reason is that they produce capital goods used by other firms to make their own products. When demand is slack, few firms will expand and purchase capital goods. Thus, capital goods producers bear the brunt of a slowdown but perform well in good times. Another reason is that these capital-intensive producers often have higher operating leverage and therefore are more exposed to business cycle fluctuations. Indeed, we find the output growth of these four industries with high sensitivities to electricity usage to have strong predictive power for future stock returns. In sharp contrast, the output growth of the remaining industries, which have modest or low sensitivity to electricity usage, has little return predictive power. This finding suggests that industrial electricity usage appears to be a good measure of output in the very cyclical industries, which explains why it performs better than the total industrial output in forecasting stock returns.

The predictability of stock returns is typically taken out of sample. Welch and Goyal (2008) show that none of the existing predicting variables outperforms the historical mean in their out-of-sample experiment. For this reason, we evaluate the performance of the industrial electricity growth rate and other return predictors using the out-of-sample test methodology of Campbell and Thompson (2008). Whereas most financial variables underperform the historical mean in the outof-sample test, the industrial electricity growth rate beats it, and by the largest margin. When compared to the other industrial-output-based measures, the only variable that outperforms industrial electricity growth is the in-sample output gap.

Because industrial electricity usage data are available only at an annual frequency in the United Kingdom and Japan, we also conduct annual predictive regressions, where the dependent variable is always excess stock returns in the next calendar year. These annual regressions allow us to examine the performance of industrial electricity growth beyond the United States and also to compare it to other output measures. Moreover, annual regressions avoid the use of overlapping samples and are less subject to statistical inference bias. Several interesting patterns emerge from these annual-horizon analyses in all three countries.

First, the annual industrial electricity usage growth rate by itself remains a good predictor of future excess stock returns; its regression $R^{2}$ values are $10.15 \%$

\footnotetext{
${ }^{3}$ See the discussion in the Federal Reserve's "Industrial Production and Capacity Utilization: The 2005 Annual Revision,” p. A50 (https://www.federalreserve.gov/pubs/bulletin/2006/ip06_2.pdf).
} 
in the United States, $6.95 \%$ in Japan, and $11 \%$ in the United Kingdom. Second, industrial electricity usage growth clearly outperforms the year-over-year output growth because when these two are combined, electricity has much higher $t$-values and lower $p$-values for all three countries. Third, when industrial electricity usage is combined with various output growth measures as analyzed by Moller and Rangvid (2015), we find that industrial electricity usually outperforms other variables. The only exception is that it underperforms the output growth of the third quarter of the current year to the fourth quarter of the current year in the United States. Finally, although Cooper and Priestley's (2009) output gap measure forecasts stock market returns better on a standalone basis, it does not drive out the electricity growth rate in the United States. In fact, industrial electricity usage growth rates often have higher $t$-values than the output gap does in head-tohead comparisons. In other words, industrial electricity usage contains valuable and incremental information that helps predict future stock returns.

We could also compare industrial electricity usage growth to investment growth rates using annual predictive regressions in the United States, where quarterly investment data are available. Not surprisingly, investment growth rates, output growth rates, and the industrial electricity growth rate are all highly correlated at annual frequency. We find that annual investment growth rates, computed from fourth quarter to fourth quarter and from third quarter to fourth quarter, have predictive power for the next year's excess stock returns. These findings provide further empirical support for the investment-based asset pricing literature. As argued by Cochrane (1991) and more recently by Lin and Zhang (2013), under fairly general assumptions, investment today should negatively predict stock returns tomorrow. Nevertheless, industrial electricity usage growth still does a much better job than investment growth in predicting future excess stock returns in univariate regressions, and it drives out investment growth in multivariate regressions. One possible reason is that the standard investment data focus only on investment in capital stock. When existing capital is utilized more intensively, more investment is also needed to maintain it. Such a maintenance investment can be large; it is estimated to be $30 \%$ of the investment in new physical capital, according to survey data from Canada (see McGrattan and Schmitz (1999)). Although comprehensive maintenance investment data are not directly available, industrial electricity usage is a good proxy because higher electricity use reflects more intensive capital utilization and implies more maintenance investment.

From a real-life investment point of view, the industrial electricity usage growth rate is, in our view, a superior return predictor because it can be easily calculated almost in real time. In contrast, the benchmark in-sample output measure described by Cooper and Priestley (2009) requires estimation using a full sample. When we compare the industrial electricity usage growth rate to the outof-sample output gap, both lagged by 2 months so that investors can use them in real time, it is clear that the former outperforms the latter completely, across all forecasting horizons.

Our paper contributes to the long line of literature on stock return predictability, such as Campbell (2003), Cochrane (2008), Lamont (2000), Lettau and Ludvigson (2001), Lustig and van Nieuwerburgh (2005), Lettau and Ludvigson (2010), Santos and Veronesi (2006), Rangvid (2006), Cooper and Priestley (2009), 
Belo and Yu (2013), and Rapach and Zhou (2013), among many others. Fama and French (1989) suggest that financial variables correlate with the business cycle and can predict stock returns. Also, behavioral variables, such as investor sentiment (Baker and Wurgler (2006), Charoenrook (2003)) and consumer confidence (Fisher and Statman (2003), Ludvigson (2004)), can also predict stock returns. Several papers, such as those by Campbell (2003), Cochrane (2008), and Lettau and Ludvigson (2009), show that price-based financial variables tend to predict stock returns better than quantity-based macroeconomic indicators. In fact, typical business cycle indicators such as GDP do not forecast stock returns (Pena et al. (2002)). We find that industrial electricity usage growth, by overweighting the most business-cycle-sensitive industries, predicts stock returns well. Our paper thus contributes to the literature by linking financial markets and the real economy.

The rest of the paper proceeds as follows: Section II describes the data and provides summary statistics for the main variables. Sections III and IV present our empirical results from monthly and annual regressions, respectively. Section V examines the predictive power in real time. Section VI concludes.

\section{Data}

\section{A. Electricity and Weather Data}

Monthly industrial electricity usage data (millions of kilowatt-hours) in the United States are manually collected from two sources published by the Energy Information Administration (EIA): Electric Power Statistics for data from 19551978 and Electric Power Monthly for data from 1979-2010. ${ }^{4}$ Because electricity consumption data can be revised by the EIA, our hand collection of vintage data minimizes any potential forward-looking bias, which is an important concern when conducting return predictability tests. The vintage data are usually available within 2 months at most. In other words, January's electricity usage is available by the end of March.

A key concern with monthly electricity usage data is the strong withinyear seasonal effects, caused by such things as weather fluctuations. For example, Figure 1 shows normalized electricity usage (Graph A) and energy degree days (EDDs) for each month (Graph B). EDDs are the sum of cooling degree days (CDDs) and heating degree days (HDDs), which measure summer and winter weather variation, respectively. ${ }^{5}$ As shown in the figure, industrial electricity

${ }^{4}$ EIA Form 826 describes the customers. The residential sector consists of living quarters for private households. The commercial sector consists of service-providing facilities, such as businesses, governments, and institutional living quarters. The industrial sector consists of facilities for producing goods, such as manufacturing (North American Industry Classification System (NAICS) codes 3133); agriculture, forestry, and hunting (NAICS code 11); mining, including oil and gas extraction (NAICS code 21); natural gas distribution (NAICS code 2212); and construction (NAICS code 23). Other customers include public street and highway lighting, public authorities, railroads and railways, and irrigation, as well as interdepartmental sales. Total electricity usage accounts for the amount used by ultimate customers and hence excludes resold or wasted amounts. It also excludes direct use, which is electricity used in power plants for generating electricity.

${ }^{5}$ Summer (winter) weather is measured by monthly cooling (heating) degree days (CDDs or HDDs), which we obtain from NOAA. The daily CDD (HDD) values capture deviations in daily 


\section{FIGURE 1}

\section{Normalized Electricity Consumption and Weather: Monthly (U.S.)}

Figure 1 shows normalized electricity usage and weather conditions. Electricity usage data are obtained from the Energy Information Administration (EIA). Weather data are obtained from the National Oceanic and Atmospheric Administration (NOAA). Graph A shows normalized residential (circle dots), commercial (square dots), and industrial (triangle dots) electricity usage. Normalized electricity usage is the average monthly consumption divided by the annual consumption over the sample period (1956-2010) for each month. Graph B plots the normalized average energy degree days (EDDs) for each month over the same period. EDDs are the sum of normalized cooling degree days (CDDs) and normalized heating degree days (HDDs), which measure summer and winter weather variation, respectively.
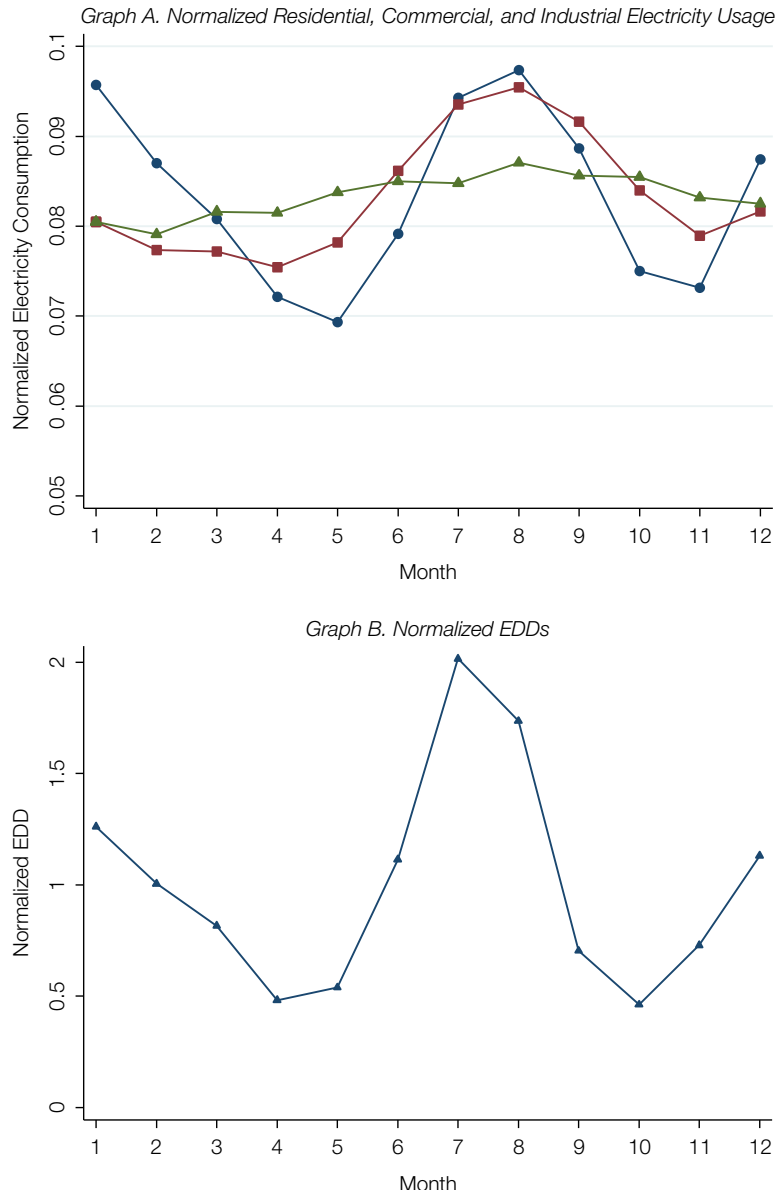

mean temperatures above (below) $65^{\circ} \mathrm{F}$, the benchmark at which energy demand is low. As an example, if the average temperature is $75^{\circ} \mathrm{F}$, the corresponding CDD value for the day is 10 , and the HDD is 0 . If the average temperature is $55^{\circ} \mathrm{F}$, the corresponding CDD value for the day is 0 , and the HDD is 10. Monthly CDD (HDD) values are the sum of the daily CDD (HDD) values in each month. CDD and HDD values are computed from mean temperatures for the United Kingdom and Japan. Mean temperatures are obtained from the Met Office Hadley Centre for the United Kingdom and from the Japan Meteorological Agency for Japan. 
usage, the focus of our paper, is stable within the year, and weather fluctuation is less likely to affect industrial electricity consumption. To further alleviate the seasonality effect, we compute year-over-year growth rates in industrial electricity usage between the same months in two successive years and thus identify differences in demand due to changes in economic conditions rather than seasonal weather effects. One may argue that year-over-year electricity usage growth is still subject to residual weather effects (for instance, if Dec. 2014 is unusually cold compared with other Decembers). To that end, we also orthogonalize yearover-year electricity growth rates on weather changes measured with EDDs. We find that residual electricity usage growth performs similarly, if not slightly better, in predicting stock returns.

Annual industrial electricity consumption data for Japan and the United Kingdom are obtained from the International Energy Agency's Energy Balances of Organization for Economic Cooperation and Development (OECD) countries.

\section{B. Output Measures}

We consider several output growth measures. Monthly industry production data are obtained from the Federal Reserve Bank of St. Louis's Economic Data (FRED) Web site (https://fred.stlouisfed.org/). With the monthly date, we can compute year-over-year output growth as the year-over-year growth rate in monthly industrial production, similar to the industrial electricity usage growth rate. Quarterly industrial production data are obtained from the Board of Governors of the Federal Reserve System (for the United States), the Office for National Statistics (for the United Kingdom), and the Ministry of Economy (for Japan). We compute two alternative annual output growth rates from these quarterly data. Output Q4-Q4 refers to the log difference of the industrial production index in the fourth quarter of a given year and in the fourth quarter of the previous year. The year-over-year growth rate alleviates seasonality in the output data. Output Q3-Q4 refers to the log difference of the industrial production index in the fourth quarter of the current year and in the third quarter of a given year. Moller and Rangvid (2015) show that output growth rates from the third to the fourth quarter of the current year predict the stock market returns of next year well. The industrial production index is subject to later revisions, and we use the final revised numbers instead of the vintage data as originally announced. This means that output growth rates are computed using more updated information than the electricity growth rates.

We collect industrial production data for 14 industries from FRED from Jan. 1972 to Dec. 2010. The purpose is to investigate how sectoral industrial production growth rates relate to the growth rate of aggregate industrial electricity usage and to provide explanations for the industrial electricity usage growth rate's ability to forecast future stock returns. We follow Kenneth French's industrial classification and focus on those 17 industries. Because industrial production data for banking, retail, and other industries are not available, we are left with 14 industries: steel, machinery, durables, fabricated products, construction, clothes, consumer products, chemicals, utilities, cars, oil, mines, transportation, and food. We compute the sectoral growth rates of industrial production as changes in the log index level of industrial production each month, relative to the level a year ago. 
We compute the output gap measure following Cooper and Priestley (2009). ${ }^{6}$ In the United States, we regress the log of monthly industrial production on a time trend and the square of the time trend. The residual is the estimated output gap. To avoid using forward-looking data, we also follow Cooper and Priestley (2009) to compute an out-of-sample output gap using expanding-rolling-window regressions. In particular, at the end of month $t$ in year $j$, we estimate the output gap regression using data from Jan. 1927 up to that month and compute the outof-sample output gap using the residual in that month. For the next month, we reestimate the output gap regression using all data from Jan. 1927 up to month $t+1$ to compute the out-of-sample output gap in month $t+1$.

In the United Kingdom and Japan, to match the frequency of the available electricity data, we use annual industry production data to compute the annual output gap. The sample period for the output gap calculation covers 1956-2010 for the United States, 1970-2008 for the United Kingdom, and 1980-2008 for Japan.

Another related measure is the capacity utilization index reported in the Federal Reserve Board's G.17 release. This index is constructed using potential output from a survey of plants and actual output, and it measures the proportion of firm capacity that is being used. We compute the growth of capacity utilization as the change in the log index level of capacity utilization in each month, relative to its level a year ago. These data are seasonally adjusted and available for 1968-2010.

Investment growth Q3-Q4 (Q4-Q4) is the growth rate of the fourth-quarter per capita investment relative to that of the current year's third quarter or the previous year's fourth quarter. Investment data are obtained from the Fed.

\section{Other Data}

Excess returns are value-weighted returns in excess of the T-bill rate and are obtained from the Web site of Kenneth French (http://mba.tuck.dartmouth.edu/ pages/faculty/ken.french/data_library.html). We also consider the forecasting variables investigated by Welch and Goyal (2008), Campbell and Thompson (2008), and Ferreira and Santa-Clara (2011). The details of these variables are as follows. The dividend-price ratio is the difference between the log of dividends and the log of prices. The earnings-price ratio is the difference between the log of earnings and the log of prices. The book-to-market ratio is the ratio of book value to market value for the Dow Jones Industrial Average. The Treasury bill rate is the secondary market rate on 3-month T-bills. The default spread is the difference of yields on BAA- and AAA-rated corporate bonds. The term spread is the difference of yields on long-term government bonds and 3-month T-bills. The net stock issue is the ratio of 12-month moving sums of net issues by stocks listed on the New York Stock Exchange (NYSE) divided by the total end-of-year market capitalization of NYSE stocks. Inflation is the change in the log of the Consumer Price Index. The long-term rate of return on government bonds is taken from Ibbotson's SBBI Yearbook. Stock return variance is computed as the sum of squared daily returns of the Standard \& Poor's (S\&P) 500. We take these data from

\footnotetext{
${ }^{6}$ We verify that the output gap we computed closely replicates the one used by Cooper and Priestley (2009) using a short overlapping sample up to 2005, when their data end.
} 
Amit Goyal's Web site (www.hec.unil.ch/agoyal); more details of data construction are provided by Welch and Goyal (2008).

The NBER expansion is the fraction of months spent in expansion in each year; monthly NBER expansion data are obtained from the NBER Web site (www.nber.org/cycles.html).

\section{Summary Statistics}

Panel A of Table 1 presents summary statistics for our main variables of interest at an annual frequency. The sample covers 1956-2010 in the United States (55 years), 1970-2008 in the United Kingdom (39 years), and 1980-2008 in Japan (29 years).

The December-to-December annual industrial electricity growth rate in the United States has a mean of $1.09 \%$ and a standard deviation of $5.69 \%$. The annual industrial electricity growth rates have lower means and are less volatile in the United Kingdom and Japan, possibly due to a shorter and more recent sample period. The weather-adjusted electricity growth rate in the United States, as a regression residual, has a mean of 0 by construction. ${ }^{7}$ Its standard deviation of $5.28 \%$ is only slightly smaller, suggesting that the bulk of the variation in the raw industrial electricity growth rate is unrelated to weather change. Similar patterns are observed in the United Kingdom and Japan as well: Orthogonalizing industrial electricity growth on weather fluctuation hardly changes its volatility. The autocorrelations for industrial electricity growth rates are relatively low: -0.0645 in the United States, 0.1086 in the United Kingdom, and 0.0309 in Japan.

The average annual (Q4-Q4) industry production growth is highest in the United States $(2.66 \%)$, followed by Japan $(2.04 \%)$, and is the lowest in the United Kingdom $(0.89 \%)$. The growth rate is most volatile in Japan $(5.23 \%)$, followed by the United States (4.53\%), then the United Kingdom (3.76\%). In the United States, not surprisingly, the December-to-December output growth rate has about the same mean as the Q4-Q4 output growth rate, but it is more volatile.

Panel A also shows that the in-sample output gap does not have a mean of 0 in all three countries because it is estimated in a regression using all available data over a longer sample period in each country. Because the output gap measures deviation from long-term trends, it is more autocorrelated than the annual growth rates of both industrial electricity usage and production. For example, the annual autocorrelation of the output gap is 0.6044 in the United States, 0.7832 in the United Kingdom, and 0.7059 in Japan.

In the United States, where quarterly investment data are available, we find investment growth rates (Q3-Q4 and Q4-Q4) to have similar means to the corresponding output growth rates, but they tend to be much more volatile.

December-to-December capital utilization in the United States has a mean of -0.0034 , with a standard deviation of 0.0466 . More months are in expansion periods than contraction periods, as shown by the mean, which is 0.8333 . There is substantial variation in EDD growth: Whereas the mean is only 0.0002 , the standard deviation is 0.0380 . We find similar patterns of EDD growth in the

\footnotetext{
${ }^{7}$ Specifically, we regress December-to-December industrial electricity growth on the Decemberto-December change in EDD and use the residuals from the regression.
} 
TABLE 1

\section{Sample Description}

Table 1 shows summary statistics (Panel A) and correlations (Panel B) for the sample. The summaries include the number of observations ( $N$ ), the mean, the standard deviation (Std. Dev.), the 10th percentile (P10), the median, the 90th percentile (P90), and the autocorrelation (Auto). The top panels of both are for the U.S. sample. Excess return is the annual value-weighted return in excess of the T-bill rate and is obtained from Kenneth French's Web site (http://mba.tuck.dartmouth.edu/pages/faculty/ken.french/data_library.html). The industrial electricity usage growth rate (EG) is the Decemberto-December year-on-year log difference of per capita industrial electricity usage, which is obtained from Electric Power Statistics (1956-1978) and Electric Power Monthly (1979-2010), both from the EIA. EG_DEC-DEC (Residual) for the United States is the residual of EG_DEC-DEC regressed on the growth of EDDs in each December, where EDD is the sum of CDDs and HDDs. CDD is defined as
$\mathrm{CDD}=\max \left[0,-\frac{T_{\max }+T_{\min }}{2}-65^{\circ}\right]$. HDD is defined as $\mathrm{HDD}=\max \left[0,65^{\circ}-\frac{T_{\max }+T_{\min }}{2}\right] \mathrm{T}_{\max }\left(T_{\min }\right.$ ) is the daily maximum (minimum) temperature. Monthly CDD (HDD) is the sum of daily CDD (HDD) values and captures deviations in mean temperatures below $65^{\circ} \mathrm{F}$, the benchmark at which energy demand is low. Weather data (CDD and HDD) are obtained from the NOAA for the United States. For the United Kingdom and Japan, CDD and HDD values are computed from mean temperatures, where mean temperatures are obtained from the Met Office Hadley Centre for the United Kingdom and the Japan Meteorological Agency for Japan. EDD_GROWTH_ANNUAL is the growth rate in annual EDD. OUTPUT_GROWTH_DEC-DEC is the log difference of the December and the prior year's December industrial production index. OUTPUT_GROWTH_Q3-Q4 (OUTPUT_GROWTH_Q4-Q4) is the log difference of the fourth quarter and third quarter (prior year's fourth quarter) industrial production index, which is obtained from the Board of Governors of the Federal Reserve System. OUTPUT_GAP is the residual of regressing the log of industrial production on time and time-squared, following the procedures of Cooper and Priestley (2009). CAPACITY_UTILIZATION_DEC-DEC is the log difference of December-to-December capacity utilization obtained from the Fed. INVESTMENT_GROWTH_Q3-Q4 (INVESTMENT_GROWTH_Q4-Q4) is the growth rate of fourth quarter per capita investment relative to that in current year's third quarter (previous year's fourth quarter). Investment data are obtained from the Fed. NBER_EXPANSION is the fraction of the month spent in expansion in each year; monthly NBER expansion data are obtained from the NBER Web site (www.nber.org/cycles.html). The middle (bottom) rows of both panels are for the United Kingdom (Japan) sample for 1970-2008 (1980-2008). Excess return is the annual MSCl log difference from the prior year in excess of the annual risk-free rate. Risk-free rates for Japan and the United Kingdom are from Datastream. Industrial electricity usage growth (EG_ANNUAL) is the log difference of the annual per capita industrial electricity usage from the prior year; industrial electricity usage data are obtained from the OECD database. EG_ANNUAL(RESIDUAL) is the residual from regressing EG_ANNUAL on EDD GROWTH_ANNUAL. OUTPUT GROWTH_Q3-Q4 (OUTPUT_GROWTH Q4-Q4) is the log difference of the fourth quarter and third quarter (prior year's fourth quarter) industrial production index, which is obtained from the Office for National Statistics (UK) and the Ministry of $E_{C}$ Conomy (Japan). The output gap is computed following the procedures of Cooper and Priestley (2009). Monthly industrial production data are obtained from the FRED Web site (http://alfred stlouisfed .org/series? $\mathrm{d}=$ INDPRO), and are available from 1927 . We regress the log of industrial production on time trend and trend-squared. The residual is the estimated output gap.

\section{Panel A. Summary Statistics}

\section{United States}

$R^{e}(t+1)$

EG_DEC-DEC

EG_DEC-DEC (RESIDUAL)

OUTPUT_GROWTH_DEC-DEC

OUTPUT_GROWTH_Q4-Q4

OUTPUT GROWTH Q3-Q4

OUTPUT GAP

CAPACITY UTILIZATION DEC-DEC

INVESTMENT GROWTH_Q4-Q4

INVESTMENT GROWTH_Q3-Q4

NBER EXPANSION

EDD GROWTH ANNUAL

\begin{tabular}{r} 
Mean \\
\hline 0.0448 \\
0.0109 \\
0.0000 \\
0.0267 \\
0.0266 \\
0.0074 \\
0.0018 \\
-0.0034 \\
0.0218 \\
0.0009 \\
0.8333 \\
0.0002
\end{tabular}

\begin{tabular}{|c|c|}
\hline Std. Dev. & P10 \\
\hline 0.1767 & -0.1795 \\
\hline 0.0569 & -0.0596 \\
\hline 0.0528 & -0.0825 \\
\hline 0.0500 & -0.0546 \\
\hline 0.0453 & -0.0528 \\
\hline 0.0191 & -0.0219 \\
\hline 0.0621 & -0.0950 \\
\hline 0.0466 & -0.0748 \\
\hline 0.0949 & -0.1193 \\
\hline 0.0436 & -0.0579 \\
\hline 0.2996 & 0.2500 \\
\hline
\end{tabular}

$\underline{\text { Median }}$
0.0896
0.0128
0.0155
0.0331
0.0299
0.0095
0.0091
0.0020
0.0460
0.0049
1.0000
0.0122

P90

\subsection{5}

0.0640

0.0629

0.0845

0.0264

0.0730

0.0730
0.0499

0.0499
0.1237

0.1237

0.0480

1.0000

(continued on next page)
Auto

$-0.1214$

$-0.0645$

0.0866

0.2190

0.2153

0.0900

$-0.1572$

0.1368 


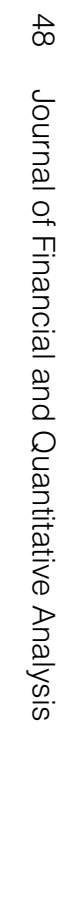


TABLE 1 (continued)

Sample Description

\begin{tabular}{|c|c|c|c|c|c|c|}
\hline \multicolumn{7}{|l|}{ Panel B. Correlations } \\
\hline United States & $R^{e}(t+1)$ & EG_DEC-DEC & EG_DEC-DEC (RESIDUAL) & OUTPUT_GROWTH_DEC-DEC & OUTPUT_GROWTH_Q4-Q4 & OUTPUT_GROWTH_Q3-Q4 \\
\hline $\begin{array}{l}\text { EG_DEC-DEC } \\
\text { EG_DEC-DEC (RESIDUAL) } \\
\text { OUTPUT_GROWTH_DEC-DEC } \\
\text { OUTPUT_GROWTH_Q4-Q4 } \\
\text { OUTPUT_GROWTH_Q3-Q4 } \\
\text { OUTPUT_GAP } \\
\text { CAPACITY_UTILIZATION } \\
\text { INVESTMENT_GROWTH_Q3-Q4 } \\
\text { INVESTMENT_GROWTH_Q4-Q4 } \\
\text { NBER_EXPANSION } \\
\text { EDD_GROWTH_ANNUAL }\end{array}$ & $\begin{array}{l}-0.3421 \\
-0.3358 \\
-0.3002 \\
-0.2751 \\
-0.3667 \\
-0.4495 \\
-0.1998 \\
-0.1964 \\
-0.2039 \\
-0.1933 \\
-0.0692\end{array}$ & $\begin{array}{l}0.9266 \\
0.6847 \\
0.6174 \\
0.6308 \\
0.3612 \\
0.6471 \\
0.5131 \\
0.6157 \\
0.6093 \\
0.2921\end{array}$ & $\begin{array}{l}0.7197 \\
0.6326 \\
0.6382 \\
0.3773 \\
0.6383 \\
0.4449 \\
0.6002 \\
0.6151 \\
0.0639\end{array}$ & $\begin{array}{l}0.9455 \\
0.7958 \\
0.383 \\
0.9249 \\
0.5414 \\
0.8699 \\
0.7993 \\
0.0323\end{array}$ & $\begin{array}{l}0.6587 \\
0.4346 \\
0.8672 \\
0.382 \\
0.8859 \\
0.7894 \\
0.0303\end{array}$ & $\begin{array}{l}0.2839 \\
0.7559 \\
0.7228 \\
0.5633 \\
0.6351 \\
0.056\end{array}$ \\
\hline United States & & $\underline{\text { OUTPUT_GAP }}$ & CAPACITY_UTILIZATION & INVESTMENT_GROWTH_Q3-Q4 & INVESTMENT_GROWTH_Q4-Q4 & NBER_EXPANSION \\
\hline $\begin{array}{l}\text { CAPACITY_UTILIZATION } \\
\text { INVESTMENT_GROWTH_Q3-Q4 } \\
\text { INVESTMENT_GROWTH_Q4-Q4 } \\
\text { NBER_EXPANSION } \\
\text { EDD_GROWTH_ANNUAL }\end{array}$ & & $\begin{array}{l}0.2389 \\
0.1371 \\
0.3307 \\
0.4672 \\
-0.035\end{array}$ & $\begin{array}{l}0.5116 \\
0.8179 \\
0.8 \\
0.2208\end{array}$ & $\begin{array}{l}0.4789 \\
0.4482 \\
0.1703\end{array}$ & $\begin{array}{l}0.7125 \\
0.0731\end{array}$ & 0.0587 \\
\hline United Kingdom & $R^{e}(t+1)$ & EG_DEC-DEC & EG_DEC-DEC (RESIDUAL) & OUTPUT_GROWTH_Q4-Q4 & OUTPUT_GROWTH_Q3-Q4 & OUTPUT_GAP \\
\hline $\begin{array}{l}\text { EG_DEC-DEC } \\
\text { EG_DEC-DEC (RESIDUAL) } \\
\text { OUTPUT_GROWTH_Q4-Q4 } \\
\text { OUTPUT_GROWTH_Q3-Q4 } \\
\text { OUTPUT_GAP } \\
\text { EDD_GROWTH_ANNUAL }\end{array}$ & $\begin{array}{l}-0.2352 \\
-0.3346 \\
-0.1072 \\
-0.2216 \\
-0.2521 \\
-0.0608\end{array}$ & $\begin{array}{l}0.8684 \\
0.5105 \\
0.4122 \\
0.2048 \\
0.1659\end{array}$ & $\begin{array}{r}0.5676 \\
0.4341 \\
0.3698 \\
0\end{array}$ & $\begin{array}{l}0.6301 \\
0.0349 \\
0.0034\end{array}$ & $\begin{array}{r}-0.1671 \\
0.0514\end{array}$ & -0.0988 \\
\hline Japan & $\underline{R^{e}(t+1)}$ & EG_DEC-DEC & EG_DEC-DEC (RESIDUAL) & OUTPUT_GROWTH_Q4-Q4 & OUTPUT_GROWTH_Q3-Q4 & OUTPUT_GAP \\
\hline $\begin{array}{l}\text { EG_ANNUAL } \\
\text { EG_ANNUAL (RESIDUAL) } \\
\text { OUTPUT_GROWTH_Q4-Q4 } \\
\text { OUTPUT_GROWTH_Q3-Q4 } \\
\text { OUTPUT_GAP } \\
\text { EDD_GROWTH_ANNUAL }\end{array}$ & $\begin{array}{r}-0.2811 \\
-0.2945 \\
-0.0373 \\
-0.1494 \\
-0.5002 \\
0.0402 \\
\end{array}$ & $\begin{array}{l}0.9817 \\
0.5663 \\
0.6557 \\
0.3037 \\
0.1956\end{array}$ & $\begin{array}{r}0.538 \\
0.6319 \\
0.3209 \\
0 \\
\end{array}$ & $\begin{array}{l}0.8087 \\
0.2243 \\
0.2027\end{array}$ & $\begin{array}{l}0.3336 \\
0.1887 \\
\end{array}$ & -0.0577 \\
\hline
\end{tabular}


FIGURE 2

Time Series of Electricity Usage and Output Growth: Annual (U.S./Japan/U.K.)

Figure 2 shows the time-series plot of industrial electricity usage and output growth measured by industrial production growth rates. Industrial electricity usage data are obtained from the EIA (the United States) and the OECD database (the United Kingdom and Japan). The industrial production index is obtained from the Board of Governors of the Federal Reserve System (the United States), the Office for National Statistics (the United Kingdom), and the Ministry of Economy (Japan). The industrial electricity usage growth rate is computed by the log difference of per capita annual industrial electricity consumption. Output growth is computed as the log difference of industrial production. Graphs A-C compare the industrial electricity usage growth rate (circle dots), Q3-Q4 output growth (rectangular dots), and Q4-Q4 output growth (triangle dots) for the United States (Graph A), the United Kingdom (Graph B), and Japan (Graph C). Electricity is measured in 1,000 MWh, and the industrial production index is seasonally adjusted and referenced relative to a base year (2007 = 100 for the United States, $2008=100$ for the United Kingdom, and $2005=100$ for Japan).
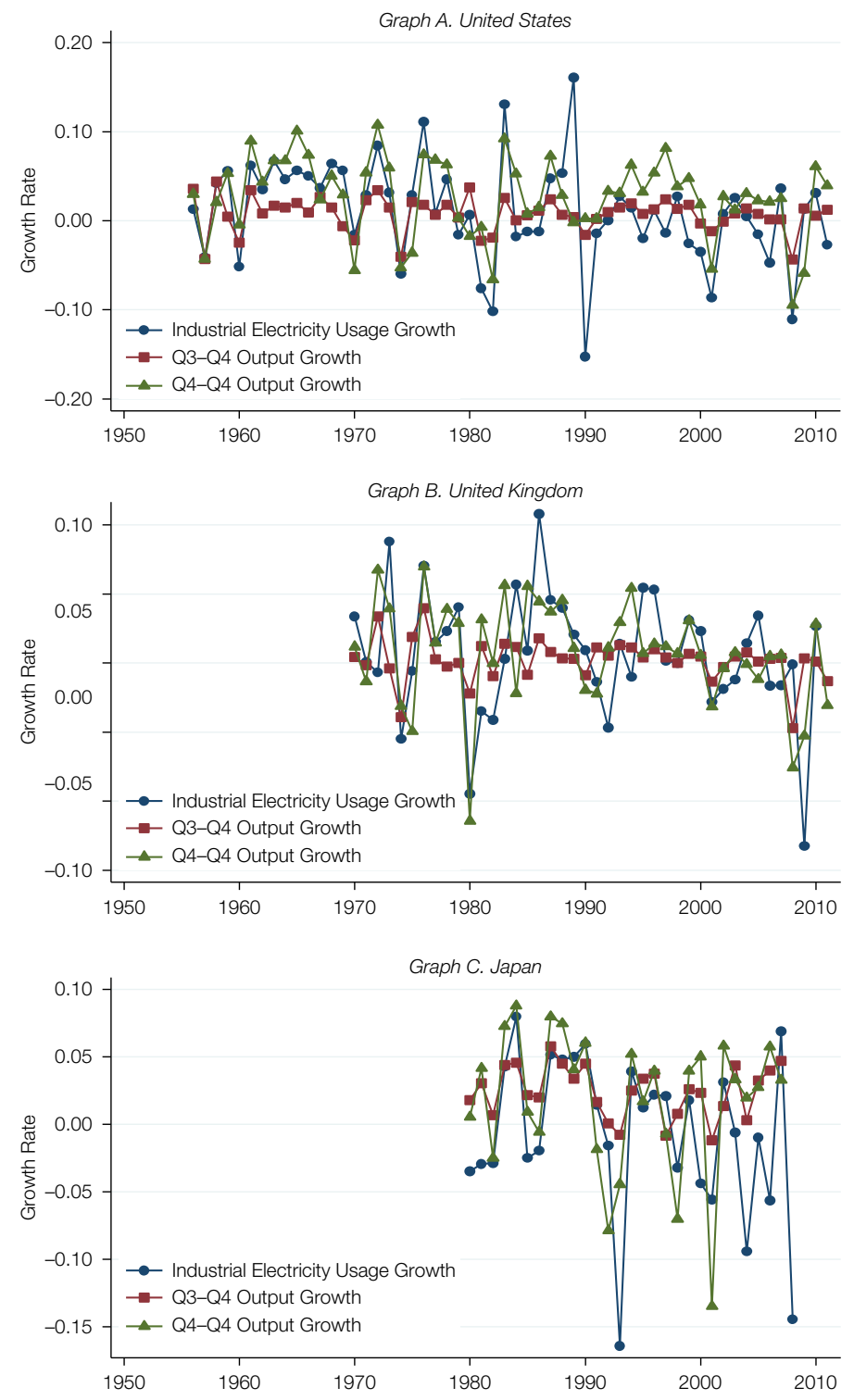
United Kingdom and Japan, where the mean is small, but the standard deviation is large.

Panel B of Table 1 reports correlations among the key variables. Several interesting patterns emerge. First, industrial electricity usage growth rates closely track the growth rates in industry production in all three countries. In the United States, the correlations between industrial electricity usage growth rates and output growth rates are above $60 \%$. Similarly, higher correlations are observed in the United Kingdom and Japan. Figure 2 provides a visualization of these high correlations, which support our view that industrial electricity usage is tracking capital services in real time. Given the high correlations with output measures, it is not surprising that the industrial electricity growth rate is a good business cycle indicator. For example, in the United States, the correlation between the industrial electricity growth rate and the NBER expansion indicator is $61 \%$. The important difference is that the industrial electricity usage growth rate is observed almost in real time, whereas NBER expansion/recession dates are often released with significant delays. The correlations between the industrial electricity growth rate and investment growth rates are also high (above 50\%).

Second, as highlighted in Figure 1, industrial electricity usage is partially driven by weather change. The correlation between December-to-December industrial electricity usage growth and annual EDD growth is $29.21 \%$ in the United States. Orthogonalizing December-to-December industrial electricity usage growth on December-to-December EDD growth greatly alleviates the weather effect. The residual has a much lower correlation, $6.39 \%$, with annual EDD growth, yet it remains highly correlated with other output measures and the business cycle indicator. Moreover, it is highly correlated $(92.66 \%)$ with the raw electricity growth rate. We find similar patterns in Japan and the United Kingdom. In both countries, the growth rates of raw annual industrial electricity usage are positively correlated with changes in annual EDD (the correlations are $16.59 \%$ (Japan) and 19.56\% (United Kingdom)). The residuals from regressing annual industrial electricity usage growth on annual EDD growth in these two countries, by construction, are uncorrelated with annual EDD growth.

Finally, in all three countries, we observe evidence that supports a countercyclical risk premium. Industry output measures in year $t$ are negatively correlated with stock market excess returns in year $t+1$, consistent with the notion that the risk premium increases during a recession. For the remainder of the paper, we will formally analyze the predictive power of the industrial electricity usage growth rate, especially relative to various measures of industry output growth.

\section{Monthly Predictive Regressions}

Because monthly industrial electricity consumption data are available in the United States, we first conduct predictive regressions at a monthly frequency in order to maximize the power of the test. To alleviate the impact of seasonality, we use a year-over-year growth rate in industrial electricity usage. For example, we use the electricity growth rate from January of year $t-1$ to January of year $t$ to predict excess stock returns in February of year $t$. Then we use the electricity growth rate from February of year $t-1$ to February of year $t$ to predict excess 
stock returns in March of year $t$, and so on. As a result, the monthly predictive regressions will be overlapping.

\section{A. The In-Sample Predictability of Electricity Growth}

In this subsection, we conduct the standard overlapping in-sample forecasting exercise. For each month from 1956 to 2010, we use a year-over-year industrial electricity usage growth rate (January to January, February to February, etc.) to predict excess, as well as actual, stock market returns in the next month, 3 months, 6 months, 9 months, and 12 months. Due to the overlapping nature of such a regression, we present the Hodrick (1992) $t$-value (Hodrick- $t$ ). In addition to persistent regressors, the evaluation of predictive regressions needs to properly account for the effect of a short sample and estimation with overlapping data. To consider persistent predictors, overlapping regressions, and a short sample simultaneously, we compute the $p$-values of coefficients through simulation, following Li et al. (2013).

We illustrate our simulation procedure using a bivariate regression where the predictive variables are industrial electricity growth (EG) and the output gap (GAP). We denote the excess return $r^{e}$.

Define a $3 \times 1$ column vector $Z_{t}=\left[r_{t}^{e}, \mathrm{EG}_{t}, \mathrm{GAP}_{t}\right]^{\prime}$. We first estimate a firstorder vector autoregression $(\operatorname{VAR}(1)): Z_{t+1}=A_{0}+A_{1} Z_{t}+u_{t+1}$. We impose the null hypothesis of no return predictability by setting the slope coefficients of the $r_{t}^{e}$ equation to 0 and the intercept of the equation to the empirical mean of $r_{t}^{e}$. The fitted VAR is then used to generate $T$ observations of the simulated variables $\left[r_{t}^{e}, \mathrm{EG}_{t}, \mathrm{GAP}_{t}\right]^{\prime}$. The initial observations are drawn from a multivariate normal distribution of the three variables, with the mean and the covariance matrix set to their empirical counterparts. Once the initial observations are chosen, the subsequent $T-1$ simulated observations are generated from the fitted VAR with the shocks bootstrapped from the actual VAR residuals (sampling without replacement). These simulated data are then used to run a bivariate return predictive regression to produce regression coefficients.

We repeat the process 50,000 times to obtain the empirical distribution of the regression coefficients (under the null of no predictability) and the $R^{2}$, which in turn produces the $p$-values associated with our actual estimated coefficients and the $p$-value associated with the $R^{2}$. The results are reported in Table 2 .

Panel A of Table 2 indicates that the simple year-over-year industrial electricity usage growth rate has strong predictive power for future excess stock market returns. In particular, an increase in industrial electricity usage today predicts lower future excess stock returns, consistent with a countercyclical risk premium. The regression slope coefficients for electricity growth are statistically highly significant. Their magnitudes increase with the forecast horizon. At the annual horizon, a $1 \%$ increase in the year-over-year electricity growth rate predicts an excess stock return that is $0.92 \%$ lower, with an $R^{2}$ of $8.64 \%$. The $p$-values at all horizons strongly reject the null hypothesis that these predicting coefficients are zeros. In addition, the $p$-values for the $R^{2}$ are also highly significant, suggesting that it very unlikely to observe our $R^{2}$ when the industrial electricity usage growth rate has no return predictive power. 
TABLE 2

Overlapping Monthly Predictive Regressions: United States (Jan. 1956-Dec. 2010)

In Table 2, for each month $t$, the industrial electricity usage growth rate is calculated as the per capita year-over-year growth rate of industrial electricity usage. We then regress future 1-month, 3-month, 6-month, 9-month, and 12-month cumulative excess returns on the industrial electricity usage growth rate and report coefficient estimates $(b)$, Hodrick $t$ values (Hodrick-t) following Hodrick (1992), $p$-values following Li et al. (2013), adjusted $R^{2}\left(R^{2}\right)$, and adjusted $R^{2}$ under the null of no predictability $\left(R^{2}-0\right)$ following Cooper and Priestley (2009). Panel A presents results from forecasting excess market returns using the raw industrial electricity usage growth rate; Panel B presents results from forecasting excess market returns using the weather-adjusted industrial electricity usage growth rate; Panels $C$ and $D$ repeat the analysis using the risk-free rate. The sample is monthly from Jan. 1956 to Dec. 2010. The U.S. stock returns and 1-month Tbill rates are obtained from Center for Research in Security Prices (CRSP) tape provided by Wharton Research Data Services. Monthly industrial electricity consumption data are obtained from Electric Power Statistics (1956-1978) and Electric Power Monthly (1979-2010), both from the EIA.

\begin{tabular}{cccccc}
\multicolumn{7}{c}{ Horizon } \\
\hline 1 & 3 & 6 & 9 & 12
\end{tabular}

Panel A. Predicting Excess Return with Electricity Growth

\begin{tabular}{|c|c|c|c|c|c|}
\hline \\
\hline$b$ & -0.0882 & -0.3088 & -0.5800 & -0.8272 & -0.9217 \\
\hline Hodrick- $t$ & -2.5202 & -3.2598 & -3.4255 & -3.5301 & -3.1787 \\
\hline$p$-value & 0.0057 & 0.0011 & 0.0014 & 0.0011 & 0.0038 \\
\hline$R^{2}$ & 0.0101 & 0.0415 & 0.0687 & 0.0916 & 0.0864 \\
\hline$p$-value $\left(R^{2}\right)$ & 0.0047 & 0.0009 & 0.0024 & 0.0023 & 0.0085 \\
\hline$R^{2}-0$ & 0.0101 & 0.0247 & 0.0367 & 0.0416 & 0.0427 \\
\hline \multicolumn{6}{|c|}{ Panel B. Predicting Excess Return with Weather-Adjusted Electricity Growth } \\
\hline$b$ & -0.0879 & -0.3075 & -0.5772 & -0.8268 & -0.9267 \\
\hline Hodrick- $t$ & -2.4856 & -3.2309 & -3.3940 & -3.5122 & -3.1863 \\
\hline$p$-value & 0.0055 & 0.0016 & 0.0018 & 0.0014 & 0.0033 \\
\hline$R^{2}$ & 0.0100 & 0.0409 & 0.0677 & 0.0911 & 0.0870 \\
\hline$p$-value $\left(R^{2}\right)$ & 0.0055 & 0.0012 & 0.0024 & 0.0029 & 0.0071 \\
\hline$R^{2}-0$ & 0.0100 & 0.0244 & 0.0365 & 0.0416 & 0.0429 \\
\hline \multicolumn{6}{|c|}{ Panel C. Predicting Risk-Free Rate with Electricity Growth } \\
\hline$b$ & 0.0013 & 0.0065 & 0.0192 & 0.0401 & 0.0623 \\
\hline Hodrick- $t$ & 0.6320 & 1.1027 & 1.6958 & 2.5141 & 3.1616 \\
\hline$p$-value & 0.2234 & 0.0978 & 0.0214 & 0.0019 & 0.0000 \\
\hline$R^{2}$ & -0.0006 & 0.0011 & 0.0040 & 0.0090 & 0.0127 \\
\hline$p$-value $\left(R^{2}\right)$ & 0.4428 & 0.4306 & 0.3939 & 0.3093 & 0.2854 \\
\hline$R^{2}-0$ & -0.0006 & -0.0015 & -0.0022 & -0.0025 & -0.0026 \\
\hline \multicolumn{6}{|c|}{ Panel D. Predicting Risk-Free Rate with Weather-Adjusted Electricity Growth } \\
\hline$b$ & 0.0011 & 0.0059 & 0.0176 & 0.0347 & 0.0529 \\
\hline Hodrick- $t$ & 0.5232 & 0.9682 & 1.5295 & 2.1549 & 2.6365 \\
\hline$p$-value & 0.2682 & 0.1229 & 0.0321 & 0.0037 & 0.0008 \\
\hline$R^{2}$ & -0.0009 & 0.0003 & 0.0026 & 0.0055 & 0.0076 \\
\hline$p$-value $\left(R^{2}\right)$ & 0.5364 & 0.4931 & 0.4333 & 0.3738 & 0.3521 \\
\hline$R^{2}-0$ & -0.0009 & -0.0021 & -0.0028 & -0.0028 & -0.0027 \\
\hline
\end{tabular}

We also report the implied $R^{2}\left(R^{2}-0\right)$ that a variable obtains under the null hypothesis of no predictability in returns, following Boudoukh, Richardson, and Whitelaw (2008) and Cooper and Priestley (2009). Specifically, the adjusted $R^{2}$ is computed as:

$$
R^{2}-0=\frac{\left(1+\frac{\rho\left(1-\rho^{k-1}\right)}{1-\rho}\right)^{2}}{k} R^{2}
$$

where $\rho$ is the autocorrelation coefficient of the predictor variable, $k$ is the horizon, and $R^{2}$ is the empirical $R^{2}$.

The implied $R^{2}$ provides us with an economic sense of how far the $R^{2}$ of a predicting variable deviates from the $R^{2}$ this variable generates, given its persistence and no predictability. For instance, given the persistence of electricity growth, even if there is no predictability in returns, the $R^{2}$ will be $4.27 \%$. But 
electricity growth's actual $R^{2}$ is $8.64 \%$, which is twice the $R^{2}$ generated under the null hypothesis of no predictability. ${ }^{8}$ It is evident that the actual $R^{2}$ values achieved by electricity growth at various forecasting horizons are substantial improvements over those produced under the null hypothesis of no predictability. Using the simulated distribution of the adjusted $R^{2}$, we confirm that these improvements are statistically significant, with the associated $p$-values overwhelmingly under $1 \%$ at all horizons.

The year-over-year electricity growth rate is still subject to weather effects, as is evident in Panel B of Table 1. To that end, we try to orthogonalize these year-over-year electricity growth rates on weather fluctuation, measured by the year-over-year growth rate in monthly EDD, so that we can focus on residual electricity usage growth. Panel B of Table 2 reports the predictive regression results using weather-adjusted electricity growth rates. The results are very similar. Overall, it is clear that seasonality and weather effects are not driving the return predictive power of industrial electricity data. We confirm that weather-adjusted electricity growth rates provide results similar to those of the raw growth rates in all other tests and in Japan and the United Kingdom as well. For brevity, in the rest of the paper, we present only results using the raw growth rates, which are easy to compute and do not suffer from forward-looking bias.

Panels C and D of Table 2 repeat the analysis from Panels A and B with risk-free rates, and we find strong predictive power as well. In particular, a higher industrial electricity growth today predicts higher risk-free rates for up to a year, suggesting that industrial electricity usage growth is highly procyclical.

\section{B. The In-Sample Predictability of Other Predictors}

To put the predictive power of industrial electricity growth into perspective, we examine 14 other monthly return predictors, one at a time, in the same monthly overlapping predictive regressions. The first 10 predictors are well-known financial variables: dividend-price ratio, earnings-price ratio, book-to-market ratio, Treasury bill rate, default spread, term spread, net equity issuance, inflation, return on long-term government bonds, and stock variance. We also consider four other measures of output growth: the in-sample output gap calculated using the full sample, the out-of-sample output gap computed using the expanding-rolling sample, the year-over-year change in capacity utilization, and the year-over-year growth rate of industrial production.

Table 3 presents the performance of these alternative predictors by themselves. Among the financial variables, judging by the $p$-values associated with the regression coefficients, inflation and long-term bond returns have significant predictive power, but their $R^{2}$ values are noticeably lower than those of the industrial electricity growth rate at all horizons. The performance of the financial ratios appears weak in our sample for two reasons. First, our sample starts in 1956 rather than in 1926. Second, our statistical inference corrects for the biases caused by having a persistent predictor in overlapping regressions. Financial ratios, which tend to be more persistent, naturally become weaker after this correction.

\footnotetext{
${ }^{8}$ For predicting next-month excess returns $(k=1)$, the two $R^{2}$ values are identical because the regression does not use an overlapping sample.
} 
TABLE 3

Alternative Predicting Variables: United States (Jan. 1956-Dec. 2010)

In Table 3, we predict future 1-month, 3-month, 6-month, 9-month, and 12-month cumulative excess returns using the following common predicting variables: dividend-price ratio, earnings-price ratio, book-to-market ratio, T-bill rate, default spread, term spread, net equity issuance, inflation, rate of return on long-term government bonds, stock variance, insample output gap, out-of-sample output gap following Cooper and Priestley (2009), capacity utilization, and year-overyear output growth. We report coefficient estimates (b), Hodrick $t$-value (Hodrick- $t$ ) following Hodrick (1992), $p$-values ( $p$-value) following Li et al. (2013), adjusted $R^{2}\left(R^{2}\right)$, and adjusted $R^{2}$ under the null of no predictability $\left(R^{2}-0\right)$. Data for the first 10 predicting variables are from Welch and Goyal (2008) and are available at http://research.ivo-welch.inf o/. The monthly output production gap is computed following Cooper and Priestley (2009). Capacity utilization is from the G.17 release from the Fed. The monthly overlapping output growth (year-over-year) is the year-over-year growth of industrial production. The sample is from Jan. 1956 to Dec. 2010, with the exception of capacity utilization, which goes from Jan. 1968 to Dec. 2010. The U.S. stock returns and 1-month T-bill rates are obtained from CRSP tape provided by Wharton Research Data Services. Monthly industrial electricity usage is obtained from Electric Power Statistics (19561978) and Electric Power Monthly (1979-2010), both from the EIA.

\begin{tabular}{|c|c|c|c|c|c|c|c|c|c|c|}
\hline & \multicolumn{10}{|c|}{ Horizon } \\
\hline & 1 & 3 & 6 & 9 & 12 & 1 & 3 & 6 & 9 & 12 \\
\hline \multirow{7}{*}{$\begin{array}{l}b \\
\text { Hodrick- } t \\
p \text {-value } \\
R^{2} \\
R^{2}-0\end{array}$} & \multicolumn{5}{|c|}{ DIVIDEND_PRICE_RATIO } & \multicolumn{5}{|c|}{ INFLATION } \\
\hline & 0.2254 & 0.7669 & 1.7795 & 2.6888 & 3.4087 & -0.9805 & -1.8017 & -3.7725 & -5.7593 & -7.2224 \\
\hline & 1.2806 & 1.4871 & 1.7516 & 1.7950 & 1.7294 & -1.5875 & -1.0809 & -1.2980 & -1.4536 & -1.4789 \\
\hline & 0.2778 & 0.2283 & 0.1777 & 0.1749 & 0.1892 & 0.0264 & 0.0743 & 0.0376 & 0.0189 & 0.0147 \\
\hline & 0.0016 & 0.0094 & 0.0259 & 0.0397 & 0.0488 & 0.0041 & 0.0042 & 0.0102 & 0.0164 & 0.0200 \\
\hline & 0.0016 & 0.0048 & 0.0092 & 0.0134 & 0.0174 & 0.0041 & 0.0052 & 0.0039 & 0.0028 & 0.0021 \\
\hline & \multicolumn{5}{|c|}{ EARNINGS_PRICE_RATIO } & \multicolumn{5}{|c|}{ LONG-TERM_GOVERNMENT_BOND_RETURN } \\
\hline$b$ & 0.0599 & 0.1692 & 0.3729 & 0.5757 & 0.7479 & 0.1621 & 0.2055 & 0.6026 & 0.6192 & 0.7038 \\
\hline Hodrick- $t$ & 0.7574 & 0.7380 & 0.8400 & 0.8916 & 0.8925 & 2.3834 & 1.6554 & 3.5713 & 3.1482 & 3.2345 \\
\hline$p$-value & 0.4788 & 0.4911 & 0.4664 & 0.4598 & 0.4676 & & 0.0319 & 0.0001 & & 0.0004 \\
\hline$R^{2}$ & -0.0002 & 0.0016 & 0.0056 & 0.0096 & 0.0128 & 0.0090 & 0.0036 & 0.0188 & 0.0126 & 0.0124 \\
\hline \multirow[t]{2}{*}{$R^{2}-0$} & -0.0002 & -0.0007 & -0.0013 & -0.0019 & -0.0025 & 0.0090 & 0.0032 & 0.0016 & 0.0011 & 0.0008 \\
\hline & \multicolumn{5}{|c|}{ BOOK-TO-MARKET_RATIO } & \multicolumn{5}{|c|}{ STOCK_VARIANCE } \\
\hline$b$ & 0.0036 & 0.0145 & 0.0389 & 0.0599 & 0.0742 & -1.0935 & -0.7940 & 1.0351 & 2.5833 & 3.1431 \\
\hline Hodrick- $t$ & 0.4535 & 0.6268 & 0.8528 & 0.8 & 0.8 & & -0 & & & 0.8706 \\
\hline$p$-value & 0.6104 & 0.5620 & 0.4927 & 0.4830 & 0.5000 & 0.0057 & 0.1856 & 0.7392 & 0.9025 & 0.9076 \\
\hline$R^{2}$ & -0.0011 & 0.0005 & 0.0054 & 0.0093 & 0.0111 & 0.0090 & 0.0002 & -0.0002 & 0.0039 & 0.0046 \\
\hline \multirow[t]{2}{*}{$R^{2}-0$} & -0.0011 & -0.0033 & -0.0064 & -0.0094 & -0.0123 & 0.0090 & 0.0092 & 0.0058 & 0.0040 & 0.0030 \\
\hline & \multicolumn{5}{|c|}{ T-BILL_RATE } & \multicolumn{5}{|c|}{ OUTPUT_GAP_IN_SAMPLE } \\
\hline$b$ & -0.0995 & -0.2325 & -0.3581 & -0.4374 & -0.5081 & -0.1107 & -0.3302 & -0.6047 & -0.8854 & -1.0921 \\
\hline Hodr & -1.4800 & -1.1688 & -0.9105 & -0.7518 & -0.6646 & -4.4891 & -4.5422 & -4.2064 & -4.1379 & -3.8296 \\
\hline$p$-value & 0.0722 & 0.1185 & 0.1754 & 0.2179 & 0.2424 & 0.0013 & 0.0014 & 0.0024 & 0.0023 & 0.0035 \\
\hline & 025 & 0.0051 & 0.0057 & 0.0055 & 0.00 & 0.0234 & 0.0652 & 0.10 & 0.1 & 0.1668 \\
\hline \multirow[t]{2}{*}{$R^{2}-0$} & 0.0025 & 0.0074 & 0.0141 & 0.0202 & 0.0258 & 0.0234 & 0.0678 & 0.1289 & 0.1840 & 0.2336 \\
\hline & \multicolumn{5}{|c|}{ DEFAULT_SPREAD } & \multicolumn{5}{|c|}{ OUTPUT_GAP_OUT_OF_SAMPLE } \\
\hline$b$ & 0.4618 & 1.6422 & 4.0262 & 5.3237 & 6.4270 & 95 & -0.1551 & 84 & -0.3 & -0.4577 \\
\hline $\mathrm{Hoc}$ & 0.9700 & 1.1984 & 1.6321 & 1.5697 & 15217 & -1.7273 & -1.8433 & -1.6891 & -1.6 & -1.4549 \\
\hline$p$-va & 0.1658 & 0.1175 & 0.0708 & 0.0934 & 0.11 & 0.0 & 0.0789 & 0.0 & 0.1067 & 0.1369 \\
\hline$R^{2}$ & 0.0007 & 0.0070 & 0.0224 & 0.0260 & 0.0292 & 0.0033 & 0.0129 & 0.0200 & 0.0271 & 0.0274 \\
\hline \multirow[t]{2}{*}{$R^{2}-0$} & 0.0007 & 0.0020 & 0.0036 & 0.0049 & 0.0060 & 0.0033 & 0.0098 & 0.0189 & 0.0273 & 0.0351 \\
\hline & \multicolumn{5}{|c|}{ TERM_SPREAD } & \multicolumn{5}{|c|}{ CAPACITY_UTILIZATION } \\
\hline$b$ & -0.0423 & -0.0504 & -0.0041 & 0.1876 & 0.3140 & -0.0575 & -0.2243 & -0.4992 & -0.7365 & -0.8442 \\
\hline ck-t & -0.5499 & -0.2238 & -0.0093 & 0.2941 & 0.3745 & -1.1408 & -1.6075 & -1.9301 & -2.0583 & -1.9408 \\
\hline$p$-value & 0.6775 & 0.5854 & 0.5254 & 0.4411 & 0.4164 & 0.1235 & 0.0658 & 0.0442 & 0.0437 & 0.0665 \\
\hline & -0.0010 & -0.0013 & -0.0015 & -0.0007 & 0.0003 & 0.0014 & 0.0133 & 0.0331 & 0.0473 & 0.0474 \\
\hline \multirow[t]{2}{*}{$R^{2}-0$} & - 00010 & -0.0030 & -0.0059 & -0.0086 & $-0,0111$ & 0.0014 & 0.0039 & 0.0071 & 0.0097 & 0.0118 \\
\hline & \multicolumn{5}{|c|}{ NET_EQUITY_ISSUANCE } & \multicolumn{5}{|c|}{ OUTPUT_GROWTH_YEAR-OVER-YEAR } \\
\hline$b$ & .0376 & 429 & 0760 & -0.1130 & -0.0863 & 25 & 351 & 61 & 902 & -0.7658 \\
\hline Hodrick- $t$ & -0.3284 & -0.1256 & -0.1108 & -0.1103 & -0.0651 & -2.3073 & -2.6507 & -2.7095 & -2.9196 & -2.6215 \\
\hline$p$-value & 0.3605 & 0.4468 & 0.4523 & 0.4535 & 0.4768 & 0.0140 & 0.0091 & 0.0090 & 0.0067 & 0.0164 \\
\hline & -0.0013 & -0.0014 & -0.0014 & -0.0013 & -0.0015 & 0.0074 & 0.0268 & 0.0480 & 0.0733 & 0.0688 \\
\hline$R^{2}-0$ & -0.0013 & -0.0036 & -0.0068 & -0.0095 & -0.0118 & 0.0074 & 0.0204 & 0.0364 & 0.0487 & 0.0581 \\
\hline
\end{tabular}

The four industrial-output-based measures predict excess stock market returns better than the financial variables. The strongest predictor among the four is the in-sample output gap. It significantly predicts stock returns at all horizons, and the accompanying adjusted $R^{2}$ values are even higher than those of the industrial 
electricity usage growth rate. However, the in-sample output gap is computed using future information, which might not be available at the time of return prediction. Therefore, we also examine the out-of-sample output gap. This new measure does not perform as well as the in-sample output gap. Its regression coefficients are marginally significant at short horizons, and its adjusted $R^{2}$ values are much lower; all are below $3 \%$.

The year-over-year change in capacity utilization significantly predicts excess stock returns beyond 1 month. Its adjusted $R^{2}$ values are much lower than those of the industrial electricity usage growth rate, and are all below $5 \%$. The year-over-year growth rate of industrial production predicts returns highly significantly at all horizons, but its adjusted $R^{2}$ values are still lower than those of the industrial electricity usage growth rate. It is interesting that industrial electricity usage predicts returns better than a direct measure of industrial output.

In Table 4, we conduct bivariate predictive regressions by combining the industrial electricity usage growth rate with the other 14 variables, one at a time.

\section{TABLE 4}

Competing with Alternative Predicting Variables: United States (Jan. 1956-Dec. 2010)

In Table 4, we predict future 1-month, 3-month, 6-month, 9-month, and 12-month cumulative excess returns using both the industrial electricity usage growth rate and one of the following predicting variables: dividend-price ratio, earnings-price ratio, book-to-market ratio, T-bill rate, default spread, term spread, net equity issuance, inflation, return on long-term government bonds, stock variance, in-sample output gap, out-of-sample output gap following Cooper and Priestley (2009), capacity utilization, and year-over-year output growth. We report coefficient estimates (b1 and b2), Hodrick $t$-value $(t(b 1)$ and $t(b 2))$ following Hodrick (1992), and $p$-values $(p(b 1)$ and $p(b 2))$ following Li et al. (2013) for electricity and alternative predicting variables, and the adjusted $R^{2}\left(R^{2}-0\right)$. Data for the first 10 predicting variables are from Welch and Goyal (2008) and are available at http://research.ivo-welch.info/. The monthly output production gap is computed following Cooper and Priestley (2009), with revised industrial production data obtained from the Fed. Capacity utilization is from the G.17 release of the Fed. The monthly overlapping output growth (year-over-year) is the year-overyear growth of revised industrial production. The sample is from Jan. 1956 to Dec. 2010, with the exception of capacity utilization, which goes from Jan. 1968 to Dec. 2010. The U.S. stock returns and 1-month T-bill rates are obtained from CRSP tape provided by Wharton Research Data Services. Monthly industrial electricity usage is obtained from Electric Power Statistics (1956-1978) and Electric Power Monthly (1979-2010), both from the EIA.

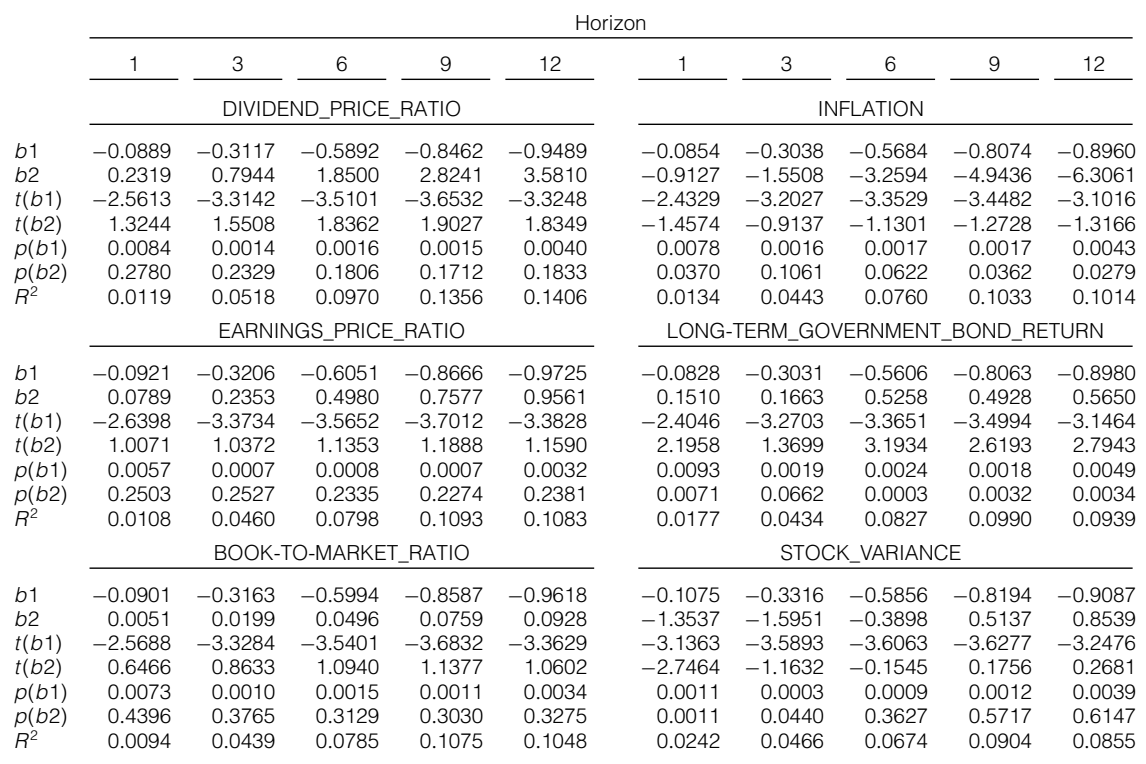

(continued on next page) 
TABLE 4 (continued)

Competing with Alternative Predicting Variables: United States (Jan. 1956-Dec. 2010)

\begin{tabular}{|c|c|c|c|c|c|c|c|c|c|c|}
\hline & \multicolumn{10}{|c|}{ Horizon } \\
\hline & 1 & 3 & 6 & 9 & 12 & 1 & 3 & 6 & 9 & 12 \\
\hline & \multicolumn{5}{|c|}{ T-BILL_RATE } & \multicolumn{5}{|c|}{ OUTPUT_GAP_IN_SAMPLE } \\
\hline $\begin{array}{l}b 1 \\
b 2 \\
t(b 1) \\
t(b 2) \\
p(b 1) \\
p(b 2) \\
R^{2}\end{array}$ & $\begin{array}{r}-0.0872 \\
-0.0962 \\
-2.5047 \\
-1.4449 \\
0.0064 \\
0.0759 \\
0.0124\end{array}$ & $\begin{array}{r}-0.3060 \\
-0.2181 \\
-3.2447 \\
-1.1133 \\
0.0015 \\
0.1335 \\
0.0459\end{array}$ & $\begin{array}{r}-0.5740 \\
-0.3185 \\
-3.4007 \\
-0.8248 \\
0.0019 \\
0.2067 \\
0.0730\end{array}$ & $\begin{array}{r}-0.8178 \\
-0.3583 \\
-3.4961 \\
-0.6279 \\
0.0016 \\
0.2625 \\
0.0949\end{array}$ & $\begin{array}{r}-0.9095 \\
-0.4065 \\
-3.1403 \\
-0.5427 \\
0.0051 \\
0.2911 \\
0.0896\end{array}$ & $\begin{array}{r}-0.0467 \\
-0.0959 \\
-1.2375 \\
-3.5481 \\
0.0990 \\
0.0028 \\
0.0247\end{array}$ & $\begin{array}{r}-0.1914 \\
-0.2685 \\
-1.8366 \\
-3.3003 \\
0.0349 \\
0.0046 \\
0.0780\end{array}$ & $\begin{array}{r}-0.3618 \\
-0.4853 \\
-1.9121 \\
-2.9763 \\
0.0329 \\
0.0074 \\
0.1244\end{array}$ & $\begin{array}{r}-0.4917 \\
-0.7177 \\
-1.8519 \\
-2.9315 \\
0.0378 \\
0.0083 \\
0.1711\end{array}$ & $\begin{array}{r}-0.4819 \\
-0.9237 \\
-1.4691 \\
-2.8512 \\
0.0831 \\
0.0095 \\
0.1855\end{array}$ \\
\hline$R^{2}$ & \multicolumn{5}{|c|}{ DEFAULT_SPREAD } & \multicolumn{5}{|c|}{ OUTPUT_GAP_OUT_OF_SAMPLE } \\
\hline $\begin{array}{l}b 1 \\
b 2 \\
t(b 1) \\
t(b 2) \\
p(b 1) \\
p(b 2) \\
R^{2}\end{array}$ & $\begin{array}{r}-0.0910 \\
-0.0680 \\
-2.4872 \\
-0.1366 \\
0.0115 \\
0.6041 \\
0.0086\end{array}$ & $\begin{array}{r}-0.3173 \\
-0.2067 \\
-3.1878 \\
-0.1433 \\
0.0025 \\
0.6073 \\
0.0402\end{array}$ & $\begin{array}{r}-0.5459 \\
0.8223 \\
-3.0164 \\
0.3159 \\
0.0046 \\
0.4194 \\
0.0680\end{array}$ & $\begin{array}{r}-0.8026 \\
0.5837 \\
-3.1007 \\
0.1598 \\
0.0035 \\
0.4812 \\
0.0904\end{array}$ & $\begin{array}{r}-0.8661 \\
1.3124 \\
-2.6702 \\
0.2869 \\
0.0092 \\
0.4406 \\
0.0860\end{array}$ & $\begin{array}{r}-0.0781 \\
-0.0292 \\
-2.1562 \\
-0.9910 \\
0.0156 \\
0.2135 \\
0.0101\end{array}$ & $\begin{array}{r}-0.2804 \\
-0.0813 \\
-2.8339 \\
-0.9302 \\
0.0038 \\
0.2286 \\
0.0437\end{array}$ & $\begin{array}{r}-0.5315 \\
-0.1349 \\
-2.9491 \\
-0.7730 \\
0.0040 \\
0.2670 \\
0.0718\end{array}$ & $\begin{array}{r}-0.7580 \\
-0.1842 \\
-2.9589 \\
-0.7053 \\
0.0037 \\
0.2847 \\
0.0957\end{array}$ & $\begin{array}{r}-0.8387 \\
-0.2160 \\
-2.5727 \\
-0.6243 \\
0.0090 \\
0.3100 \\
0.0908\end{array}$ \\
\hline$R^{2}$ & \multicolumn{5}{|c|}{ TERM_SPREAD } & \multicolumn{5}{|c|}{ CAPACITY_UTILIZATION } \\
\hline $\begin{array}{l}b 1 \\
b 2 \\
t(b 1) \\
t(b 2) \\
p(b 1) \\
p(b 2) \\
R^{2}\end{array}$ & $\begin{array}{r}-0.0915 \\
-0.0671 \\
-2.5796 \\
-0.8700 \\
0.0054 \\
0.7523 \\
0.0098\end{array}$ & $\begin{array}{r}-0.3153 \\
-0.1337 \\
-3.2793 \\
-0.5970 \\
0.0010 \\
0.6769 \\
0.0415\end{array}$ & $\begin{array}{r}-0.5868 \\
-0.1497 \\
-3.4356 \\
-0.3477 \\
0.0015 \\
0.6027 \\
0.0681\end{array}$ & $\begin{array}{r}-0.8274 \\
-0.0036 \\
-3.4992 \\
-0.0058 \\
0.0011 \\
0.5050 \\
0.0901\end{array}$ & $\begin{array}{r}-0.9172 \\
0.1079 \\
-3.1274 \\
0.1313 \\
0.0050 \\
0.4682 \\
0.0852\end{array}$ & $\begin{array}{r}-0.1632 \\
0.0911 \\
-2.6813 \\
1.2091 \\
0.0058 \\
0.8884 \\
0.0130\end{array}$ & $\begin{array}{r}-0.4836 \\
0.2171 \\
-3.1358 \\
1.1240 \\
0.0029 \\
0.8564 \\
0.0477\end{array}$ & $\begin{array}{r}-0.7458 \\
0.1827 \\
-2.6656 \\
0.4950 \\
0.0061 \\
0.6891 \\
0.0724\end{array}$ & $\begin{array}{r}-0.9497 \\
0.1276 \\
-2.3461 \\
0.2430 \\
0.0093 \\
0.6064 \\
0.0895\end{array}$ & $\begin{array}{r}-1.0919 \\
0.1467 \\
-2.1079 \\
0.2229 \\
0.0148 \\
0.6024 \\
0.0901\end{array}$ \\
\hline$R^{2}$ & \multicolumn{5}{|c|}{ NET_EQUITY_ISSUANCE } & \multicolumn{5}{|c|}{ OUTPUT_GROWTH_YEAR-OVER-YEAR } \\
\hline $\begin{array}{l}b 1 \\
b 2 \\
t(b 1) \\
t(b 2) \\
p(b 1) \\
p(b 2) \\
R^{2}\end{array}$ & $\begin{array}{r}-0.0947 \\
0.0560 \\
-2.6681 \\
0.4846 \\
0.0055 \\
0.6903 \\
0.0091\end{array}$ & $\begin{array}{r}-0.3436 \\
0.2978 \\
-3.5935 \\
0.8589 \\
0.0004 \\
0.8204 \\
0.0442\end{array}$ & $\begin{array}{r}-0.6472 \\
0.5685 \\
-3.7734 \\
0.8100 \\
0.0006 \\
0.8179 \\
0.0743\end{array}$ & $\begin{array}{r}-0.9214 \\
0.7954 \\
-3.8100 \\
0.7508 \\
0.0007 \\
0.8054 \\
0.0993\end{array}$ & $\begin{array}{r}-1.0317 \\
0.9279 \\
-3.3894 \\
0.6725 \\
0.0016 \\
0.7753 \\
0.0945\end{array}$ & $\begin{array}{r}-0.0705 \\
-0.0217 \\
-1.2850 \\
-0.4434 \\
0.0887 \\
0.3305 \\
0.0089\end{array}$ & $\begin{array}{r}-0.2836 \\
-0.0309 \\
-2.0120 \\
-0.2365 \\
0.0230 \\
0.4252 \\
0.0403\end{array}$ & $\begin{array}{r}-0.5005 \\
-0.0971 \\
-1.9496 \\
-0.3829 \\
0.0224 \\
0.3625 \\
0.0682\end{array}$ & $\begin{array}{r}-0.6275 \\
-0.2424 \\
-1.7329 \\
-0.6678 \\
0.0327 \\
0.2584 \\
0.0940\end{array}$ & $\begin{array}{r}-0.7041 \\
-0.2630 \\
-1.5439 \\
-0.5765 \\
0.0475 \\
0.2890 \\
0.0884\end{array}$ \\
\hline
\end{tabular}

The results are consistent and striking. When combined with each of the 14 additional predictive variables, electricity growth rate remains significant across the board for forecasting horizons up to 1 year. In fact, it drives out 8 of the $10 \mathrm{fi}$ nancial variables; the inflation rate and long-term bond returns are the only exceptions. It is important to note that these financial variables are computed using price or return information, whereas the industrial electricity usage growth rate is a quantity-based variable.

Interestingly, although the industrial electricity usage growth rate is highly correlated with the other four industrial-output-based measures, it outperforms three of these four measures in the bivariate regressions. The only exception is the in-sample output gap. Both the industrial electricity usage growth rate and the insample output gap are significant when they are included in the same regression, suggesting that they are complementary.

\section{An Anatomy of Industrial Production}

How can industrial electricity usage, presumably proxying industrial production, outperform a direct measure of industrial production based on the final release from the Fed in predicting future stock returns? 
We first examine the possibility that industrial electricity usage is a more timely measure of industrial production. The vintage industrial electricity usage growth rate in month $t$ indeed positively and significantly predicts the future revision in the month- $t$ industrial production (defined as final release minus initial vintage) with a coefficient of 0.0191 and a $t$-value of 2.35 . However, the magnitude of the revision in industrial production is very small ( $0.5 \%$ on average). In other words, the vintage industrial production should be quite accurate already. In addition, even growth rates computed from the revised industrial production still underperform the industrial electricity usage growth rate computed using vintage electricity data.

We then zoom in on the industrial components of the total industrial output. We focus on 17 industries, as described on Kenneth French's Web site. Because industrial production is not available for banking, retail, and other industries, we are left with 14 industries: steel, machinery, durables, fabricated products, construction, clothes, consumer products, chemicals, utilities, cars, oil, mines, transportation, and food. We first regress the year-over-year output growth in each industry on the aggregate industrial electricity usage growth rate. The regression beta measures how sensitive the output of that industry is to industrial electricity usage. These coefficients are reported in Panel A of Table 5.

Four industries have betas that are equal to or larger than 1: steel (1.84), machinery (1.27), fabricated products (1.03), and construction (1.00). These industries are likely to be capital intensive, which is consistent with the high sensitivity of their output to industrial electricity usage.

The output growth rates of these four industries turn out to be highly cyclical. This is evident in Figure 3, where we plot the average year-over-year industrial production growth rates of these industries with the solid line. For comparison, we also plot the same growth rates of the four industries with the lowest sensitivity to electricity usage (cars, transportation, chemicals, and food) with the dashed line. The shaded bars mark NBER recession dates. It is clear that the solid line tracks business cycles more closely. We see large dips during recessions. In contrast, we do not always see dips in the dashed line during recessions.

There are at least two reasons why outputs from the steel, machinery, fabricated products, and construction industries are more cyclical. First, they produce capital goods used by other firms to produce their own products. When demand is slack, few firms will expand and purchase capital goods. As such, capital goods producers bear the brunt of a slowdown but perform well in good times. Another reason is that these capital-intensive producers often have higher operating leverage and therefore are more exposed to business cycle fluctuations.

Indeed, we find the output growth of these four industries with high sensitivity to electricity usage to have strong predictive power for future stock returns. These results are reported in Panel B of Table 5. Only the output growth rates of these four industries can significantly predict future excess stock returns. The output growth rates of industries with medium or low sensitivity to electricity usage have little return predictive power.

Industrial electricity usage turns out to be a good measure of the output of the very cyclical industries in particular, which explains why it performs better than total industrial output in predicting stock returns. 
TABLE 5

Industry Electricity Sensitivity: United States (Jan. 1972-Dec. 2010)

In Panel A of Table 5, we regress the year-over-year output growth of each industry on aggregate year-over-year per capita industrial electricity usage growth. We report coefficient estimates (COEFF) and $t$-values following Newey and West (1987) (NW_T). We consider the following industries: steel, machinery (Machn), durables, fabricated products (FabPr), construction (Cnstr), clothes (Clths), consumer products (Cnsum), chemicals (Chems), utilities (Utils), cars, oil, mines, transportation (Trans), and food. In Panel B, we predict future 1-month, 3-month, 6-month, 9-month, and 12-month cumulative excess returns using the average of the year-over-year output growth of industries with high, medium, and low electricity sensitivity. We report coefficient estimates (b), Hodrick $t$-value (Hodrick- $t$ ) following Hodrick (1992), $p$ values following Li et al. (2013), the adjusted $R^{2}$, and the adjusted $R^{2}$ under the null of no predictability $\left(R^{2}-0\right)$. Data on industry-level output is the industrial production index from the G.17 release of the Federal Reserve Board. The sample is from Jan. 1972 to Dec. 2010.

Panel A. Regressing Output Growth on Electricity Growth

\begin{tabular}{|c|c|c|c|c|c|}
\hline \multicolumn{3}{|c|}{ High Electricity Sensitivity } & \multicolumn{3}{|c|}{ Low Electricity Sensitivity } \\
\hline Industry & COEFF & NW_T & Industry & COEFF & NW_T \\
\hline Steel & 1.8391 & 9.4581 & Cars & 0.3044 & 1.4821 \\
\hline Machn & 1.2666 & 8.6210 & Trans & 0.2704 & 1.5114 \\
\hline FabPr & 1.0348 & 7.6708 & Chems & 0.2576 & 2.3998 \\
\hline Cnstr & 1.0045 & 6.6275 & Food & 0.1094 & 2.0445 \\
\hline \multicolumn{6}{|c|}{ Medium Electricity Sensitivity } \\
\hline Industry & $\underline{\text { COEFF }}$ & $\underline{N W \_T}$ & Industry & $\underline{\text { COEFF }}$ & NW_T \\
\hline Durbl & 0.9976 & 6.7686 & Utils & 0.3604 & 8.6415 \\
\hline Clths & 0.8326 & 3.1260 & Oil & 0.3412 & 3.5443 \\
\hline Cnsum & 0.3909 & 6.1487 & Mines & 0.3396 & 5.5345 \\
\hline
\end{tabular}

Panel B. Predicting Return Using Output Growth

\begin{tabular}{|c|c|c|c|c|c|}
\hline \multicolumn{6}{|c|}{ izon } \\
\hline & 1 & 3 & 6 & 9 & 12 \\
\hline \multicolumn{6}{|c|}{ Panel B1. High Electricity Sensitivity } \\
\hline$b$ & -0.0593 & -0.1833 & -0.3409 & -0.4521 & -0.4557 \\
\hline Hodrick- $t$ & -2.1364 & -2.3678 & -2.4300 & -2.3354 & -1.9752 \\
\hline$p$-value & 0.0239 & 0.0202 & 0.0262 & 0.0376 & 0.0877 \\
\hline$R^{2}$ & 0.0095 & 0.0318 & 0.0535 & 0.0616 & 0.0472 \\
\hline$R^{2}-0$ & 0.0095 & 0.0267 & 0.0489 & 0.0672 & 0.0823 \\
\hline \multicolumn{6}{|c|}{ Panel B2. Medium Electricity Sensitivity } \\
\hline$b$ & -0.0519 & -0.1800 & -0.2577 & -0.3284 & -0.2960 \\
\hline Hodrick- $t$ & -0.7370 & -0.9620 & -0.7533 & -0.6924 & -0.5027 \\
\hline$p$-value & 0.0512 & 0.0302 & 0.0852 & 0.1178 & 0.2111 \\
\hline$R^{2}$ & -0.0004 & 0.0044 & 0.0042 & 0.0047 & 0.0020 \\
\hline$R^{2}-0$ & -0.0004 & -0.0011 & -0.0019 & -0.0025 & -0.0029 \\
\hline \multicolumn{6}{|c|}{ Panel B3. Low Electricity Sensitivity } \\
\hline$b$ & -0.0385 & -0.0997 & -0.1998 & -0.3090 & -0.3595 \\
\hline Hodrick- $t$ & -0.7072 & -0.6564 & -0.6912 & -0.7325 & -0.6395 \\
\hline$p$-value & 0.2266 & 0.2536 & 0.2453 & 0.2363 & 0.2605 \\
\hline$R^{2}$ & -0.0009 & 0.0005 & 0.0030 & 0.0057 & 0.0055 \\
\hline$R^{2}-0$ & -0.0009 & -0.0024 & -0.0039 & -0.0048 & -0.0053 \\
\hline
\end{tabular}

\section{Out-of-Sample Predictability}

The predictability of stock returns is often taken out of sample. Welch and Goyal (2008) show that none of the existing predicting variables outperforms the historical mean in their out-of-sample experiment. ${ }^{9}$ We generate our out-ofsample forecast with a sequence of expanding samples, and we require 5 years of data for the initial forecast. In particular, we use information up to time $t$ and estimate the following equation, counting the fitted values from the estimation as

${ }^{9}$ This result is overturned when Campbell and Thompson (2008) put restrictions on the out-ofsample exercise. These restrictions include proper signs on the coefficient estimates and a positive sign on the forecasted risk premium. 


\section{FIGURE 3}

Average Output Growth of Industries with High/Low Electricity Sensitivity

In Figure 3, we plot the average year-on-year output growth of industries with high (thick solid line) and low (thin dashed line) electricity sensitivity. The industries with high electricity sensitivity are steel, machinery, fabricated products, and construction. The industries with low electricity sensitivity are cars, transportation, chemicals, and food. The sample is from Jan. 1972 to Dec. 2010.

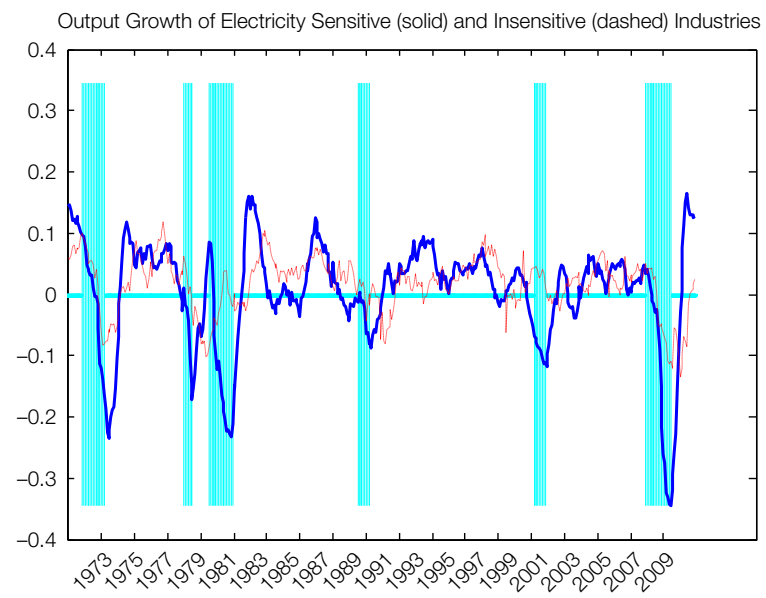

the forecasted equity premium for time $t+1$ :

$$
r_{t}=\alpha+\beta x_{t-1}+\epsilon_{t},
$$

where $r_{t}$ is the excess return at time $t, x_{t-1}$ is a predicting variable at time $t-1$, $\epsilon_{t}$ is the residual, and $\alpha$ and $\beta$ are coefficients. We follow this process, increasing the sample by one additional observation each time, and thereby generate a series of out-of-sample equity premium forecasts, $\hat{\mu}_{t}, \hat{\mu}_{t+1}, \ldots, \hat{\mu}_{T-1}$. The out-of-sample $R^{2}$ then compares the mean-squared errors for a specific predicting variable to those achieved when using historical means:

$$
R^{2}=1-\frac{\sum_{i=s_{0}}^{T-1}\left(r_{t+1}-\hat{\mu}_{i}\right)^{2}}{\sum_{i=s_{0}}^{T-1}\left(r_{t+1}-\bar{r}_{i}\right)^{2}},
$$

where $\bar{r}_{i}$ is the historical mean of returns up to time $i, s_{0}$ equals 60 months, and $T$ is the number of observations in the sample. For robustness, we also consider a rolling method in which we always keep 10 years of data to estimate equation (6). This approach is different from the previous one in that the starting observation is not fixed, and at any point, our sample for estimation contains 10 years of monthly data.

Table 6 reports the out-of-sample forecasting performance of electricity growth and the other 14 predictive variables examined in Tables 3 and 4. 
TABLE 6

Out-of-Sample Test: United States (Jan. 1956-Dec. 2010)

In Table 6, we use information up to time $t$ and estimate

$$
r_{t}=\alpha+\beta x_{t-1}+\varepsilon_{t},
$$

where $x_{t-1}$ is the industrial electricity usage growth rate, and $r_{t}$ is the 1-month-ahead excess return. We then count the fitted value, $\hat{\mu}_{t}$, from the estimation as the forecasted equity premium for time $t+1$ :

$$
\hat{\mu}_{t}=\hat{\alpha}+\hat{\beta} x_{t-1} \text {. }
$$

We either increase the sample by one additional observation each time (fixed) or have a rolling sample of 10 years of data (rolling) and thereby generate a series of out-of-sample equity premium forecasts, $\hat{\mu}_{t}, \hat{\mu}_{t+1}, \ldots, \hat{\mu}_{T-1}$. Following Campbell and Thompson (2008) and Welch and Goyal (2008), the out-of-sample $R^{2}$ compares the mean-squared errors for a specific predicting variable to those achieved when using historical means:

$$
R^{2}=1-\frac{\sum_{i=s_{0}}^{T-1}\left(r_{i+1}-\hat{\mu}_{i}\right)^{2}}{\sum_{i=s_{0}}^{T-1}\left(r_{i+1}-\bar{r}_{i}\right)^{2}},
$$

where $\bar{r}_{i}$ is the historical mean of returns up to time $i$, and $T$ is the number of observations in our sample. We require $s_{0}$ to be 60 months when we expand the sample and 10 years when we roll the sample. In each case, we consider three scenarios: i) without any restrictions; ii) with sign restrictions, which sets premia estimates to the historical mean when coefficient signs are incorrect; and iii) premia restrictions, which set premia estimates to 0 when forecasted premia are negative. We compete with the following predicting variables: price-dividend ratio, price-earnings ratio, market-tobook ratio, T-bill rate, default spread, term spread, net equity issuance, inflation, rate of return on long-term government bonds, stock variance, in-sample output gap, out-of-sample output gap following Cooper and Priestley (2009), capacity utilization, and year-over-year output growth. The U.S. stock returns and 1-month T-bill rates are obtained from CRSP tape provided by Wharton Research Data Services. Monthly industrial electricity usage data are obtained from Electric Power Statistics (1956-1978) and Electric Power Monthly (1979-2010), both from the EIA.

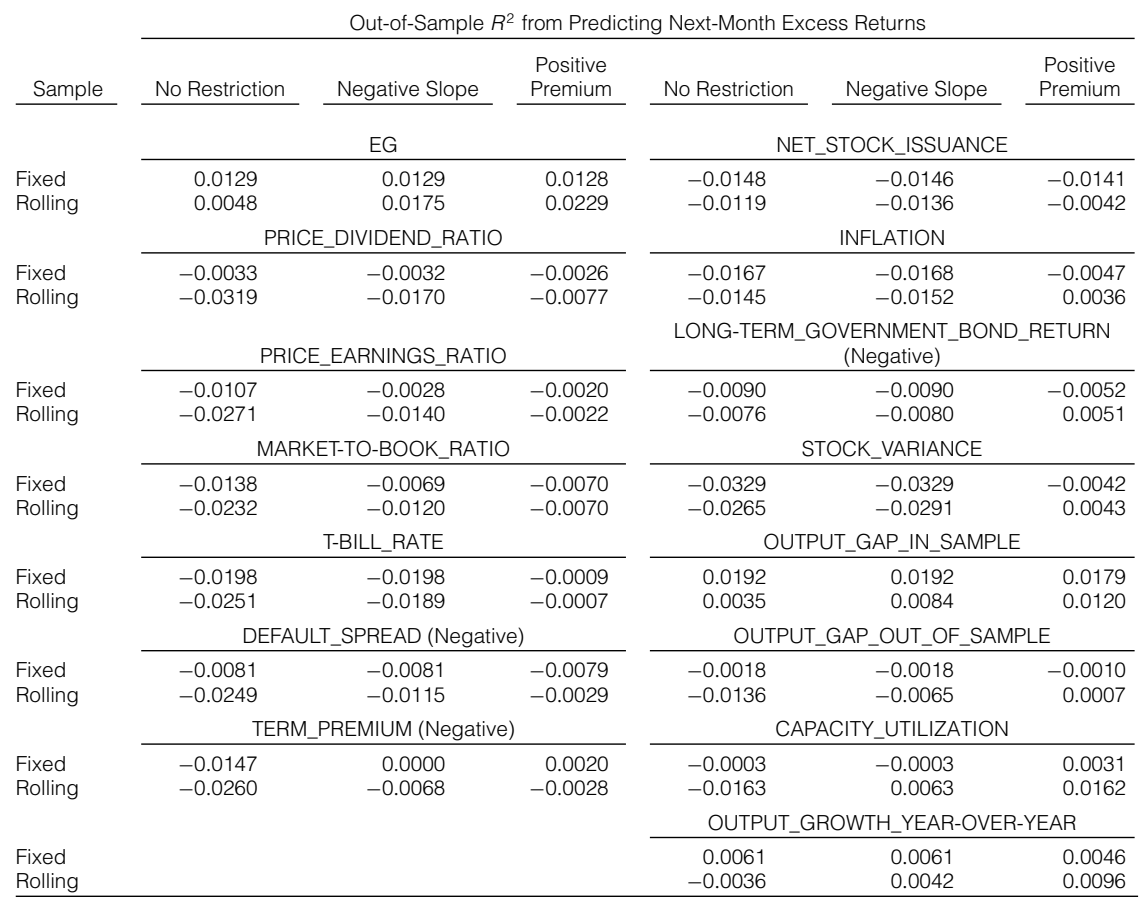

We consider three scenarios. The first column in Table 6 is the simple outof-sample $R^{2}$, without any restrictions. It shows that only the industrial electricity usage growth rate, the in-sample output gap, and year-over-year output growth outperform historical mean methodology in forecasting the future equity premium out of sample. Among the three variables, when using an expanding in-sample window with a fixed starting point, the in-sample output gap has the 
highest out-of-sample $R$-squared (1.92\%), followed by the industrial electricity usage growth rate $(1.29 \%)$ and year-over-year output growth $(0.61 \%)$. If, however, a fixed-length rolling window is used, electricity growth has the highest $R^{2}$, $0.48 \%$.

The second column of Table 6 requires the slope estimates to have the correct signs. If the sign restrictions are violated, we set the risk premium forecast to the historical mean. This method primarily prevents the poor performance of term premium because it often has the wrong sign. The restriction, however, hardly improves the performance of price multiples and interest rate variables. Again, the industrial electricity usage growth rate, the in-sample output gap, and year-over-year output growth outperform historical mean methodology in forecasting the future equity premium out of sample. The industrial electricity usage growth rate has the highest out-of-sample $R^{2}, 1.75 \%$, when a fixed-length rolling window is used.

The third column in Table 6 requires risk premium forecasts to be positive. If one is negative, then it is set to 0 . This column shows that the performance of most forecasting variables is improved, but the industrial electricity usage growth rate remains the best predictor of the future equity premium out-of-sample when a fixed-length rolling window is used.

Overall, the industrial electricity usage growth rate and the in-sample output gap are the only two predictors that consistently beat the historical mean in predicting future stock excess returns. Although in general the out-of-sample $R^{2}$ is small, Campbell and Thompson (2008) provide an approach for evaluating whether the small increase is economically meaningful for mean-variance investors.

A positive out-of-sample $R^{2}$ means that the predictor outperforms the historical mean. In that case, a mean-variance investor can optimally allocate his or her assets between the stock market and a risk-free asset and can enhance his or her return by using this predictor (rather than the historical average). Campbell and Thompson (2008) show that this return enhancement is approximately outof-sample $R^{2} / \gamma$, where $\gamma$ measures relative risk aversion.

The industrial electricity usage growth rate has monthly out-of-sample $R^{2}$ values varying between $0.48 \%$ and $2.29 \%$ when we roll the sample, and of approximately $1.28 \%$ when we fix the sample starting point in estimation. If the relative risk aversion for an average mean-variance investor is 3, these numbers translate into annual excess return gains of $1.92 \%, 9.16 \%$, and $5.12 \%$.

\section{Annual Predictive Regressions}

Because industrial electricity usage data are available only at an annual frequency in the United Kingdom and Japan, we also conduct annual predictive regressions where the dependent variable is always the calendar-year excess stock returns. These annual regressions allow us to examine the performance of electricity growth beyond the United States and also against other output measures, some of which can be computed only at annual frequencies (e.g., Q3-Q4 growth in industry production). In addition, annual regressions avoid the use of overlapping samples, which may cause statistical inference bias. Because sample size is 
further reduced with annual data, we still compute simulated $p$-values as in the previous section to address the statistical issues associated with having persistent predictors in a small overlapping sample.

Table 7 reports the results from in-sample univariate regressions on one predictive variable at a time. Panel A contains the results for the United States. Consistent with the results shown in Table 2, December-to-December industrial electricity growth strongly and negatively predicts future excess stock returns, with an $R^{2}$ of more than $10 \%$.

Consistent with the findings of Cooper and Priestley (2009), the output gap measure calculated using the full sample seems to be the best predictor so far. Not only is it statistically significant in the monthly and annual samples, but also it is associated with the highest $R^{2}$ values (18.49\% in the annual regression). Consistent with the results of Moller and Rangvid (2015), growth rates in industry production, especially those from the third quarter to the fourth quarter, also significantly and negatively predict future excess stock returns. The performance of the output growth rate from the fourth quarter to the fourth quarter rate is slightly weaker. Interestingly, December-to-December output growth also performs well,

\section{TABLE 7}

\section{International Annual Regressions}

In Table 7, we predict 1-year future excess returns using the per capita industrial electricity usage growth rate and other macro predicting variables. The annual industrial electricity usage growth rate (ELECTRICITY_GROWTH) in the United States is the log difference of the current December's per capita industrial electricity consumption and the previous December's per capita industrial electricity consumption. Annual output growth (OUTPUT_GROWTH_DEC$\mathrm{DEC}$ ) in the United States is the log difference of the current December's industrial production and the previous December's industrial production. Other output growths are based on the growth rates of fourth-quarter industrial production (OUTPUT_GROWTH_Q4-Q4) relative to either the previous year's fourth-quarter industrial production or the current year's third-quarter industrial production (OUTPUT_GROWTH_Q3-Q4). The output gap (in sample) is computed following the procedures of Cooper and Priestley (2009). We use revised industry production data. Investment growth rates are the growth rate of fourth-quarter per capita investment relative to those in the previous year's fourth quarter (INVESTMENT_GROWTH_Q4-Q4) or the current year's third quarter (INVESTMENT_GROWTH_Q3-Q4). Annual industrial electricity usage data for Japan and the United Kingdom are from the OECD database. Population data are from the World Bank. Risk-free rates for Japan and the United Kingdom are from Datastream. Industrial electricity usage data are from the EIA (United States) and the OECD database (United Kingdom and Japan). The industrial production index is obtained from the Board of Governors of the Federal Reserve System (United States), the Office for National Statistics (United Kingdom), and the Ministry of Economy (Japan). In each regression, we report the coefficient estimates (b), Hodrick $t$-value (Hodrick- $t$ ) following Hodrick (1992), $p$-value, and adjusted $R^{2}\left(R^{2}\right)$.

\begin{tabular}{|c|c|c|c|c|}
\hline Variable & $b$ & Hodrick- $t$ & $p$-Value & $R^{2}$ \\
\hline \multicolumn{5}{|l|}{ Panel A. United States (1956-2010) } \\
\hline $\begin{array}{l}\text { ELECTRICITY_GROWTH } \\
\text { OUTPUT_GROWTH_DEC-DEC } \\
\text { OUTPUT_GROWTH_Q4-Q4 } \\
\text { OUTPUT_GROWTH_Q3-Q4 } \\
\text { OUTPUT_GAP } \\
\text { INVESTMENT_GROWTH_Q4-Q4 } \\
\text { INVESTMENT_GROWTH_Q3-Q4 }\end{array}$ & $\begin{array}{l}-1.1171 \\
-1.1008 \\
-0.9987 \\
-2.4157 \\
-1.3368 \\
-0.3949 \\
-0.8457\end{array}$ & $\begin{array}{l}-3.2836 \\
-2.6362 \\
-2.1198 \\
-2.3093 \\
-3.4993 \\
-1.6477 \\
-1.7694\end{array}$ & $\begin{array}{l}0.0053 \\
0.0169 \\
0.0311 \\
0.0236 \\
0.0027 \\
0.0841 \\
0.0649\end{array}$ & $\begin{array}{l}0.1015 \\
0.0703 \\
0.0553 \\
0.0591 \\
0.1849 \\
0.0223 \\
0.0214\end{array}$ \\
\hline \multicolumn{5}{|l|}{ Panel B. Japan (1980-2008) } \\
\hline $\begin{array}{l}\text { ELECTRICITY_GROWTH } \\
\text { OUTPUT_GROWTH_Q4-Q4 } \\
\text { OUTPUT_GROWTH_Q3-Q4 } \\
\text { OUTPUT_GAP }\end{array}$ & $\begin{array}{r}-1.2033 \\
0.0225 \\
-0.4989 \\
-2.2046\end{array}$ & $\begin{array}{r}-1.7959 \\
0.0296 \\
-0.2432 \\
-2.8126\end{array}$ & $\begin{array}{l}0.0565 \\
0.4378 \\
0.4804 \\
0.0331\end{array}$ & $\begin{array}{r}0.0695 \\
-0.0434 \\
-0.0416 \\
0.2224\end{array}$ \\
\hline \multicolumn{5}{|c|}{ Panel C. United Kingdom (1970-2008) } \\
\hline $\begin{array}{l}\text { ELECTRICITY_GROWTH } \\
\text { OUTPUT_GROWTH_Q4-Q4 } \\
\text { OUTPUT_GROWTH_Q3-Q4 } \\
\text { OUTPUT_GAP }\end{array}$ & $\begin{array}{l}-2.4217 \\
-1.0160 \\
-3.9847 \\
-1.4227\end{array}$ & $\begin{array}{l}-1.5827 \\
-0.9386 \\
-1.1229 \\
-1.8081\end{array}$ & $\begin{array}{l}0.0141 \\
0.1886 \\
0.0622 \\
0.0976\end{array}$ & $\begin{array}{r}0.1100 \\
-0.0022 \\
0.0371 \\
0.0466\end{array}$ \\
\hline
\end{tabular}


with an $R^{2}$ of $7.03 \%$, but this is less than that achieved by the industrial electricity usage growth rate.

Panel B of Table 7 reports the results for Japan. Again, the industrial electricity usage growth rate performs well. The coefficient on electricity growth is marginally significant according to the Hodrick $t$-value $(-1.79)$, but based on $p$ values from the simulations, it has a $p$-value of $5.7 \%$, which is much stronger than the $p$-values of more than $40 \%$ that Q3-Q4 and Q4-Q4 output growth have. These weaker results may arise because we are restricted to annual industrial electricity usage data in Japan, over a much shorter sample period of 29 years. The in-sample output gap remains the strongest predictor in Japan, with an $R^{2}$ of $22.24 \%$, and it has a highly significant regression coefficient.

Panel $\mathrm{C}$ of Table 7 reports the results for the United Kingdom. Industrial electricity growth is the best predictor among the four, with the highest $R^{2}(11 \%)$. The coefficient on electricity growth has a Hodrick $t$-value of -1.58 and a $p$-value of $1.4 \%$ from simulations. Output growth measures perform modestly well. The Q3-Q4 output growth produces marginally significant results. Moreover, the in-sample output gap comes with a marginally significant coefficient and a lower $R^{2}$ of $4.66 \%$.

More directly, we compare the industrial electricity growth rate with the previous output measures, one at a time, in the same annual predictive regressions. The results are presented in Table 8 and can be summarized as follows: First, when combined, industrial electricity usage growth rates always drive out Decemberover-December output growth, possibly because industry electricity usage is a more timely measure of output. Second, when the industrial electricity usage growth rate is combined with Moller and Rangvid's (2015) Q3-Q4 or Q4-Q4 output growth, we find that it usually outperforms, as evidenced by its relatively larger $t$-values and much smaller $p$-values; the one exception is when it is compared to Q3-Q4 output growth in the United States. Third, the in-sample output gap does not drive out the industrial electricity usage growth rate in the United States. In fact, the industrial electricity usage growth rate has higher $t$-values and lower $p$-values than the output gap. These results suggest that industrial electricity usage contains valuable and incremental information that helps to predict future stock returns. Finally, beyond the United States, it is unclear whether the in-sample output gap is strictly a better predictor than the industrial electricity usage growth rate. Although it outperforms the industrial electricity usage growth rate in Japan, it does not in the United Kingdom.

We could also compare industrial electricity usage growth to investment growth rates using annual predictive regressions in the United States, where quarterly investment data are available. Panel A of Table 7 shows that annual investment growth rates, computed from fourth quarter to fourth quarter and from third quarter to fourth quarter, both have a marginally significant predictive power for next-year excess stock returns ( $p$-values $=0.08$ and 0.06 , respectively). These findings provide further empirical support for the investment-based asset pricing literature. As argued by Cochrane (1991) and more recently by Lin and Zhang (2013), under fairly general assumptions, investment today should negatively predict stock returns tomorrow. Nevertheless, industrial electricity usage growth still 
does a much better job than investment growth in predicting future excess stock returns in a univariate regression.

Panel A of Table 8 shows that industrial electricity usage growth completely drives out investment growth in multivariate regressions. One possible reason is that the standard investment data focus only on investment in capital stock. When existing capital is utilized more intensively, more investment is needed to maintain it. This maintenance investment can be large; it is estimated to be $30 \%$ of the investment in new physical capital according to survey data from Canada (see McGrattan and Schmitz (1999)). Although comprehensive maintenance investment data are not directly available, industrial electricity usage is a good proxy because higher electricity use reflects more intensive capital utilization and thus implies more maintenance investment.

Even at an annual frequency, the industrial electricity usage growth rate remains a robust predictor of future excess stock returns. Horse-race tests suggest that it compares favorably against growth rates in industry production and has incremental predictive power over the output gap.

\section{TABLE 8}

Competing with Output Measures: Annual (U.S./Japan/U.K.)

In Table 8, we combine the per capita industrial electricity usage growth rate with various measures of output growth, real per capita gross domestic investment growth, or the output gap to predict 1-year-ahead excess stock returns. Annual output growth (OUTPUT_GROWTH_DEC-DEC) in the United States is the log difference of the current December's industrial production and the previous December's industrial production. Annual industrial electricity usage growth in the United States is the log difference of the current December's per capita industrial electricity consumption and the previous December's per capita industrial electricity consumption. Other output growth rates are based on the growth rates of fourth-quarter industrial production relative to either the previous year's fourth-quarter industrial production (OUTPUT_GROWTH_Q4-Q4) or the current year's third-quarter industrial production (OUTPUT_GROWTH_Q3Q4). The output gap (in sample) is computed following the procedures of Cooper and Priestley (2009). We use revised industry production data. Investment growth rates are the growth rate of fourth-quarter per capita investment relative to those in the previous year's fourth quarter (INVESTMENT_GROWTH_Q4-Q4) or the current year's third quarter (INVESTMENT_GROWTH_Q3-Q4) . Annual industrial electricity usage data for Japan and the United Kingdom are from the OECD database. Population data are from the World Bank. Industrial electricity usage data are from the EIA (United States) and the OECD database (United Kingdom and Japan). The industrial production index is obtained from the Board of Governors of the Federal Reserve System (United States), the Office for National Statistics (United Kingdom), and the Ministry of Economy (Japan). We report coefficient estimates for industrial electricity growth ( $b 1)$ and for alternative predicting variables (b2), their Hodrick $t$-values $(t(b 1)$ and $t(b 2))$, their $p$-values $(p(b 1)$ and $p(b 2))$, and their adjusted $R^{2}$ values $\left(R^{2}\right)$.

\begin{tabular}{|c|c|c|c|c|c|c|c|}
\hline Competing Variable & $b 1$ & $b 2$ & $t(b 1)$ & $t(b 2)$ & $p(b 1)$ & $p(b 2)$ & $R^{2}$ \\
\hline \multicolumn{8}{|l|}{$\underline{\text { Panel A. United States }}$} \\
\hline $\begin{array}{l}\text { OUTPUT_GROWTH_DEC-DEC } \\
\text { OUTPUT_GROWTH_Q4-Q4 } \\
\text { OUTPUT_GROWTH_Q3-Q4 } \\
\text { OUTPUT_GAP } \\
\text { INVESTMENT_GROWTH_Q4-Q4 } \\
\text { INVESTMENT_GROWTH_Q3-Q4 }\end{array}$ & $\begin{array}{l}-0.8626 \\
-0.9234 \\
-0.6069 \\
-1.1823 \\
-1.1487 \\
-1.0666\end{array}$ & $\begin{array}{r}-0.4257 \\
-0.3973 \\
-2.4080 \\
-0.9366 \\
0.0310 \\
-0.1279\end{array}$ & $\begin{array}{l}-2.1103 \\
-2.6341 \\
-1.3199 \\
-3.5731 \\
-2.6817 \\
-2.5945\end{array}$ & $\begin{array}{r}-0.8063 \\
-0.7092 \\
-1.8132 \\
-2.4414 \\
0.1055 \\
-0.2217\end{array}$ & $\begin{array}{l}0.0853 \\
0.0571 \\
0.1571 \\
0.0039 \\
0.0242 \\
0.0265\end{array}$ & $\begin{array}{l}0.3115 \\
0.3391 \\
0.0842 \\
0.0202 \\
0.5707 \\
0.4177\end{array}$ & $\begin{array}{l}0.0911 \\
0.0899 \\
0.1224 \\
0.1913 \\
0.0840 \\
0.0845\end{array}$ \\
\hline \multicolumn{8}{|l|}{ Panel B. Japan } \\
\hline $\begin{array}{l}\text { OUTPUT_GROWTH_Q4-Q4 } \\
\text { OUTPUT_GROWTH_Q3-Q4 } \\
\text { OUTPUT_GAP }\end{array}$ & $\begin{array}{l}-1.1635 \\
-1.1267 \\
-0.4660\end{array}$ & $\begin{array}{r}0.5780 \\
1.3387 \\
-1.6608\end{array}$ & $\begin{array}{l}-1.2316 \\
-1.2762 \\
-0.6605\end{array}$ & $\begin{array}{r}0.5953 \\
0.5706 \\
-2.0925\end{array}$ & $\begin{array}{l}0.1101 \\
0.1310 \\
0.2668\end{array}$ & $\begin{array}{l}0.7655 \\
0.7260 \\
0.0951\end{array}$ & $\begin{array}{r}-0.0235 \\
-0.0296 \\
0.1114\end{array}$ \\
\hline \multicolumn{8}{|l|}{ Panel C. United Kingdom } \\
\hline $\begin{array}{l}\text { OUTPUT_GROWTH_Q4-Q4 } \\
\text { OUTPUT_GROWTH_Q3-Q4 } \\
\text { OUTPUT_GAP }\end{array}$ & $\begin{array}{l}-2.7188 \\
-2.0974 \\
-2.0417\end{array}$ & $\begin{array}{r}0.5220 \\
-1.8786 \\
-0.7879\end{array}$ & $\begin{array}{l}-1.6371 \\
-1.2261 \\
-1.2246\end{array}$ & $\begin{array}{r}0.4229 \\
-0.4670 \\
-0.9448\end{array}$ & $\begin{array}{l}0.0165 \\
0.0376 \\
0.0347\end{array}$ & $\begin{array}{l}0.6658 \\
0.2755 \\
0.2729\end{array}$ & $\begin{array}{l}0.0903 \\
0.0979 \\
0.1054\end{array}$ \\
\hline
\end{tabular}




\section{Predictive Regressions in Real Time}

So far, our comparison between the industrial electricity usage growth rate and the output gap has not taken into account the data-reporting delay. For example, whereas we use vintage (first-release) data for electricity, we use the final revised data for industrial production, which could be available only 6 or 7 months after the first release. For better comparison, in this section, we recompute output gap measures using vintage industrial production data.

Historically, and especially during the early parts of our sample, even vintage data (for both electricity usage and industrial production) are released with a delay of up to 2 months. In other words, vintage electricity usage and vintage industrial production data from month $t$ sometimes reach investors only at the end of month $t+2$. To account for this reporting lag, we follow the practice of Cooper and Priestley (2009); we lag the predictive variables by 2 months in our monthly predictive regressions. For example, we use the industrial electricity usage growth rate from January of year $t-1$ to January in year $t$ and the output gap in January of year $t$ to predict excess stock returns in April of year $t$.

Panel A of Table 9 reports the results from these predictive regressions. With a 2-month lag, the predictive power of the industrial electricity usage growth rate becomes weaker with the presence of the output gap. It remains significant for predicting excess stock returns up to the next 6 months.

Panel B of Table 9 reports the results from using the in-sample output gap computed with vintage data and the same 2-month lag. The in-sample output gap remains a significant return predictor at all horizons, although the $R^{2}$ values drop significantly from those reported in Table 3. For example, at a 1-year horizon, the $R^{2}$ is $13.39 \%$, compared with $23.36 \%$ when revised data are used with no lag.

However, the in-sample output gap, even with the 2-month lag, cannot be used by an investor in real time because it is estimated using the full sample of industry production data from 1927 to 2010. In Panel C of Table 9, we examine the out-of-sample output gap instead. As in Panel A, we use the out-of-sample output gap in month $t$ to predict excess stock returns in month $t+3$. We observe no significant predictability in this case.

Panels D and E of Table 9 compare the electricity growth rate to the insample and out-of-sample output gaps, both in real time. It is evident now that the electricity growth rate adds incremental forecast power to the in-sample output gap and is strictly preferred to the out-of-sample output gap because the former drives out the latter completely across all forecasting horizons. Unreported out-ofsample tests similar to those in Table 6 suggest that when implemented in real time using only data available at the time of prediction, although the lagged industrial electricity usage growth rate beats the historical mean, the out-of-sample output gap does not. Going forward, industrial electricity usage data are likely to be observed in real time, making this approach even more appealing to an average investor. 
In Table 9, we combine the monthly per capita industrial electricity usage growth rate with the monthly output gap of Cooper and Priestley (2009) to predict future 1-month, 3-month, 6-month, 9-month, and 12-month cumulative excess returns. We lag the per capita industrial electricity usage growth rate by 2 months to account for reporting lags. Panel $A$ uses the electricity usage growth rate. The output gap estimates in Panel B use vintage industrial production data and the full sample, and the estimates in Panel $\mathrm{C}$ use vintage data and a rolling sample where we extend the sample by 1 month for an estimate in each month. We report the coefficient estimate $(b)$, Hodrick- $t, p$-value of the coefficient estimate, and adjusted $R^{2}$ value $\left(R^{2}\right)$. Panels $\mathrm{D}$ and $\mathrm{E}$ present results obtained from combining the electricity usage growth rate with the output gap. We report coefficient estimates for the industrial electricity usage growth rate $(b 1)$ and for alternative predicting variables (b2), which are the output gap, their Hodrick $t$-values $(t(b 1)$ and $t(b 2))$, their $p$-values $(p(b 1)$ and $p(b 2))$, and their adjusted $R^{2}$ values $\left(R^{2}\right)$. The sample is monthly from Jan. 1956 to Dec. 2010.

\begin{tabular}{|c|c|c|c|c|c|}
\hline & \multicolumn{5}{|c|}{ Horizon } \\
\hline & 1 & 3 & 6 & 9 & 12 \\
\hline \multicolumn{6}{|c|}{ Panel A. Electricity Growth } \\
\hline $\begin{array}{l}b \\
\text { Hodrick- } t \\
p \text {-value } \\
R^{2}\end{array}$ & $\begin{array}{r}-0.1126 \\
-3.3590 \\
0.0009 \\
0.0169\end{array}$ & $\begin{array}{r}-0.3215 \\
-3.4953 \\
0.0005 \\
0.0438\end{array}$ & $\begin{array}{r}-0.5703 \\
-3.4345 \\
0.0010 \\
0.0641\end{array}$ & $\begin{array}{r}-0.7894 \\
-3.3634 \\
0.0014 \\
0.0805\end{array}$ & $\begin{array}{r}-0.8246 \\
-2.8073 \\
0.0069 \\
0.0667\end{array}$ \\
\hline \multicolumn{6}{|c|}{ Panel B. Output Gap (In-Sample) } \\
\hline $\begin{array}{l}b \\
\text { Hodrick- } t \\
p \text {-value } \\
R^{2}\end{array}$ & $\begin{array}{r}-0.1002 \\
-3.9661 \\
0.0027 \\
0.0215\end{array}$ & $\begin{array}{r}-0.2879 \\
-3.7875 \\
0.0033 \\
0.0560\end{array}$ & $\begin{array}{r}-0.5434 \\
-3.5736 \\
0.0045 \\
0.0938\end{array}$ & $\begin{array}{r}-0.7684 \\
-3.3395 \\
0.0058 \\
0.1231\end{array}$ & $\begin{array}{r}-0.9219 \\
-2.9710 \\
0.0089 \\
0.1339\end{array}$ \\
\hline \multicolumn{6}{|c|}{ Panel C. Output Gap (Out-of-Sample) } \\
\hline $\begin{array}{l}b \\
\text { Hodrick- } t \\
p \text {-value } \\
R^{2}\end{array}$ & $\begin{array}{r}-0.0174 \\
-0.8613 \\
0.2810 \\
-0.0004\end{array}$ & $\begin{array}{r}-0.0522 \\
-0.8894 \\
0.2799 \\
0.0014\end{array}$ & $\begin{array}{r}-0.1009 \\
-0.8870 \\
0.2853 \\
0.0036\end{array}$ & $\begin{array}{r}-0.1394 \\
-0.8374 \\
0.3038 \\
0.0049\end{array}$ & $\begin{array}{r}-0.1362 \\
-0.6252 \\
0.3560 \\
0.0031\end{array}$ \\
\hline \multicolumn{6}{|c|}{ Panel D. Electricity Growth + Output Gap (In-Sample) } \\
\hline $\begin{array}{l}b 1 \\
b 2 \\
t(b 1) \\
t(b 2) \\
p(b 1) \\
p(b 2) \\
R^{2}\end{array}$ & $\begin{array}{r}-0.0820 \\
-0.0805 \\
-2.2487 \\
-2.9022 \\
0.0100 \\
0.0071 \\
0.0290\end{array}$ & $\begin{array}{r}-0.2327 \\
-0.2315 \\
-2.2955 \\
-2.7619 \\
0.0096 \\
0.0079 \\
0.0761\end{array}$ & $\begin{array}{r}-0.3932 \\
-0.4458 \\
-2.1488 \\
-2.6654 \\
0.0188 \\
0.0086 \\
0.1206\end{array}$ & $\begin{array}{r}-0.5275 \\
-0.6321 \\
-2.0204 \\
-2.4901 \\
0.0240 \\
0.0116 \\
0.1545\end{array}$ & $\begin{array}{r}-0.4942 \\
-0.7919 \\
-1.5278 \\
-2.3401 \\
0.0738 \\
0.0147 \\
0.1544\end{array}$ \\
\hline \multicolumn{6}{|c|}{ Panel E. Electricity Growth + Output Gap (Out-of-Sample) } \\
\hline $\begin{array}{l}b 1 \\
b 2 \\
t(b 1) \\
t(b 2) \\
p(b 1) \\
p(b 2) \\
R^{2}\end{array}$ & $\begin{array}{r}-0.1223 \\
0.0149 \\
-3.4297 \\
0.7193 \\
0.0006 \\
0.7359 \\
0.0161\end{array}$ & $\begin{array}{r}-0.3480 \\
0.0403 \\
-3.5599 \\
0.6662 \\
0.0007 \\
0.7182 \\
0.0438\end{array}$ & $\begin{array}{r}-0.6146 \\
0.0654 \\
-3.4251 \\
0.5431 \\
0.0013 \\
0.6887 \\
0.0644\end{array}$ & $\begin{array}{r}-0.8600 \\
0.1007 \\
-3.3135 \\
0.5561 \\
0.0013 \\
0.6943 \\
0.0818\end{array}$ & $\begin{array}{r}-0.9111 \\
0.1227 \\
-2.7764 \\
0.5104 \\
0.0059 \\
0.6844 \\
0.0683\end{array}$ \\
\hline
\end{tabular}

\section{Conclusion}

Stock return predictability has important implications for asset pricing, portfolio choice, and risk management. In this paper, we show that a simple growth rate in industrial electricity usage does a remarkable job of predicting future stock returns up to 1 year, with an $R^{2}$ of around $10 \%$. Specifically, high industrial electricity usage today predicts low stock returns in the future, which is consistent with the presence of a countercyclical risk premium. Industrial electricity usage forecasts excess returns particularly well because it tracks the output of the very cyclical sectors, such as steel and machinery. Our findings thus bridge a gap between the asset pricing literature and the traditional business cycle literature that uses industrial electricity consumption to gauge production and output in real time. 
As an empirical return predictor, the industrial electricity usage growth rate compares favorably with traditional financial variables and output-based measures, and it beats the output gap measure of Cooper and Priestley (2009) when used in real time.

Our paper also illustrates the usefulness of electricity data in financial applications. The availability of high-frequency, real-time electricity data over different geographic areas could lead to further applications in finance and economics. ${ }^{10}$ We leave this for future studies.

\section{References}

Baker, M., and J. Wurgler. "Investor Sentiment and the Cross-Section of Stock Returns." Journal of Finance, 51 (2006), 1645-1680.

Bansal, R., and A. Yaron. "Risks for the Long Run: A Potential Resolution of Asset Pricing Puzzles." Journal of Finance, 59 (2004), 1481-1509.

Belo, F., and J. Yu. "Government Investment and the Stock Market." Journal of Monetary Economics, 60 (2013), 325-339.

Boudoukh, J.; M. Richardson; and R. Whitelaw. "The Myth of Long-Horizon Predictability." Review of Financial Studies, 21 (2008), 1577-1605.

Burnside, C.; M. Eichenbaum; and S. Rebelo. "Capacity Utilization and Returns to Scale." NBER Macroeconomics Annual, 1995 (1995), 67-110.

Burnside, C.; M. Eichenbaum; and S. Rebelo. "Sectoral Solow Residuals." European Economic Review, 40 (1996), 861-869.

Campbell, J. Y. "Consumption-Based Asset Pricing." In Handbook of the Economics of Finance, Vol. IB, G. Constantinides, M. Harris, and R. Stulz, eds. Amsterdam, Netherlands: North-Holland (2003), 803-887.

Campbell, J. Y., and J. H. Cochrane. "By Force of Habit: A Consumption-Based Explanation of Aggregate Stock Market Behavior.” Journal of Political Economy, 107 (1999), 205-251.

Campbell, J. Y., and S. Thompson. "Predicting the Equity Premium Out of Sample: Can Anything Beat the Historical Average?" Review of Financial Studies, 21 (2008), 1509-1531.

Charoenrook, A. “Does Sentiment Matter?” Working Paper, Vanderbilt University (2003).

Cochrane, J. H. "Production-Based Asset Pricing and the Link between Stock Returns and Economic Fluctuations." Journal of Finance, 46 (1991), 209-237.

Cochrane, J. H. "The Dog That Did Not Bark: A Defense of Return Predictability." Review of Financial Studies, 21 (2008), 1533-1575.

Comin, D., and M. Gertler. "Medium-Term Business Cycles.” American Economic Review, 96 (2006), 523-551.

Cooper, I., and R. Priestley. "Time-Varying Risk Premiums and the Output Gap." Review of Financial Studies, 22 (2009), 2801-2833.

Da, Z.; W. Yang; and H. Yun. "Household Production and Asset Prices." Management Science, 62 (2016), 387-409.

Fama, E., and K. French. "Business Conditions and Expected Returns on Stocks and Bonds." Journal of Financial Economics, 25 (1989), 23-49.

Ferreira, M. A., and P. Santa-Clara. "Forecasting Stock Market Returns: The Sum of the Parts Is More than the Whole." Journal of Financial Economics, 100 (2011), 514-537.

Ferson, W., and J. Lin. "Alpha and Performance Measurement: The Effects of Investor Heterogeneity." Journal of Finance, 69 (2014), 1565-1596.

Fisher, K., and M. Statman. "Consumer Confidence and Stock Returns.” Journal of Portfolio Management, 30 (2003), 115-127.

Hodrick, R. J. "Dividend Yields and Expected Stock Returns: Alternative Procedures for Inference and Measurement." Review of Financial Studies, 5 (1992), 357-386.

Jorgenson, D. W., and Z. Griliches. "The Explanation of Productivity Change." Review of Economic Studies, 34 (1967), 249-283.

\footnotetext{
${ }^{10}$ As recent examples, Da, Yang, and Yun (2016) use residential electricity consumption to measure household production, and Ferson and Lin (2014) use electricity usage across different states as the proxy for investor heterogeneity in a study of mutual fund performance.
} 
King, R. G., and S. Rebello. "Resuscitating Real Business Cycles.” In Handbook of Macroeconomics, J. Taylor and M. Woodford, eds. Amsterdam, Netherlands: North-Holland (2000), 927-1007.

Lamont, O. "Investment Plans and Stock Returns." Journal of Finance, 55 (2000), 2719-2745.

Lettau, M., and S. Ludvigson. "Consumption, Aggregate Wealth, and Expected Returns." Journal of Finance, 55 (2001), 815-849.

Lettau, M., and S. Ludvigson. "Euler Equation Errors." Review of Economic Dynamics, 12 (2009), 255-283.

Lettau, M., and S. Ludvigson. "Measuring and Modeling Variation in the Risk-Return Trade-Off." In Handbook of Financial Econometrics, Y. Ait-Sahalia and L. Hansen, eds. Amsterdam, Netherlands: North-Holland (2010), 617-690.

Li, E. X. N.; D. Livdan; and L. Zhang. "Anomalies.” Review of Financial Studies, 22 (2009), 4301-4334.

Li, Y.; D. T. Ng; and B. Swaminathan. "Predicting Market Returns Using Aggregate Implied Cost of Capital." Journal of Financial Economics, 110 (2013), 419-436.

Lin, X., and L. Zhang. "The Investment Manifesto." Journal of Monetary Economics, 60 (2013), $351-366$.

Liu, L. X.; T. M. Whited; and L. Zhang. "Investment-Based Expected Stock Returns." Journal of Political Economy, 117 (2009), 1105-1139.

Ludvigson, S. "Consumer Confidence and Consumer Spending." Journal of Economic Perspectives, 18 (2004), 29-50.

Lustig, H., and S. van Nieuwerburgh. "Housing Collateral, Consumption Insurance, and Risk Premia: An Empirical Perspective." Journal of Finance, 60 (2005), 1167-1219.

McGrattan, E., and J. Schmitz. "Maintenance and Repair: Too Big to Ignore." Federal Reserve Bank of Minneapolis Quarterly Review, 23 (1999), 2-13.

Moller, S. V., and J. Rangvid. "End-of-the-Year Economic Growth and Time-Varying Expected Returns." Journal of Financial Economics, 115 (2015), 136-154.

Newey, W. K., and K. D. West. "A Simple, Positive Semi-Definite, Heteroskedasticity and Autocorrelation Consistent Covariance Matrix.” Econometrica, 55 (1987), 703-708.

Pena, I. J.; F. Restoy; and R. Rodriguez. "Can Output Explain the Predictability and Volatility of Stock Returns?” Journal of International Money and Finance, 21 (2002), 163-182.

Rangvid, J. "Output and Expected Returns." Journal of Financial Economics, 81 (2006), 595-624.

Rapach, D., and G. Zhou. "Forecasting Stock Returns." In Handbook of Economic Forecasting, G. Elliott and A. Timmermann, eds. Amsterdam, Netherlands: North-Holland (2013), 328-383.

Santos, T., and P. Veronesi. "Labor Income and Predictable Stock Returns." Review of Financial Studies, 19 (2006), 1-44.

Stambaugh, R. F. “Predictive Regressions.” Journal of Financial Economics, 54 (1999), 375-421.

Welch, I., and A. Goyal. "A Comprehensive Look at the Empirical Performance of Equity Premium Prediction." Review of Financial Studies, 21 (2008), 1455-1508.

Zhang, L. "The Value Premium." Journal of Finance, 60 (2005), 67-103. 